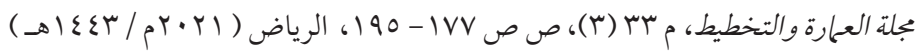

doi:10.33948/JAP-KSU-33-3-1

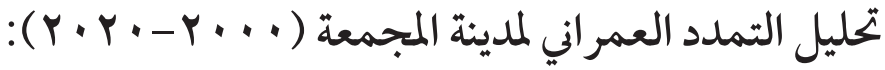 دراسة باستخدام التقنيات الجيومكانية وبيانات الأقمار الصناعية
}

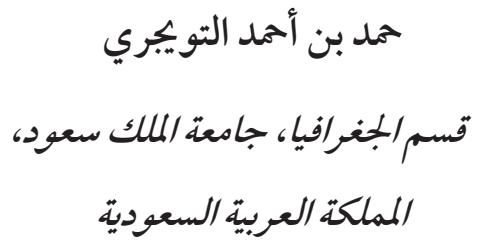

haaltuwaijri@ksu.edu.sa

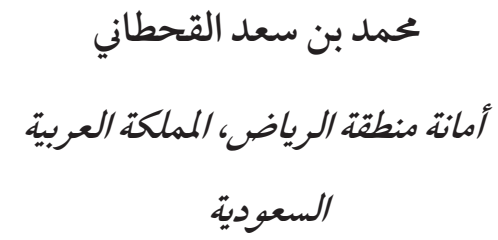

Engm7md77@gmail.com

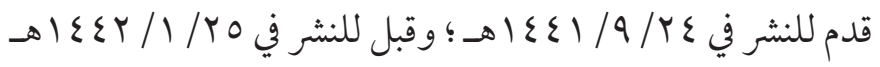

ملخص البحث. تناولت هذه الدراسة تحليل التغيّرات في أنماط الغطاء الأرضي، خاصةً تغيرات العمران على (هلى

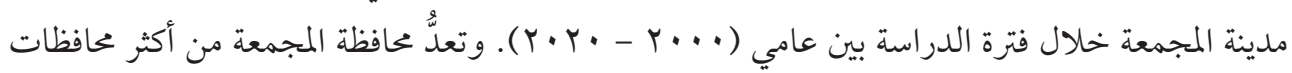
منطقة الرياض من حيث التعداد السكاني، حيث تحتل المركز الثالث على مستوى محافظات منطقة الرياض.

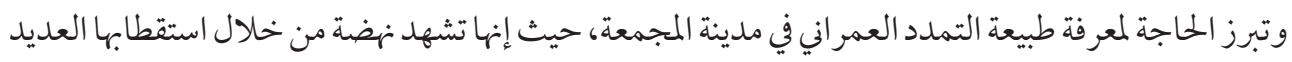

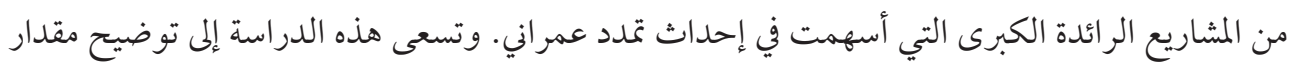

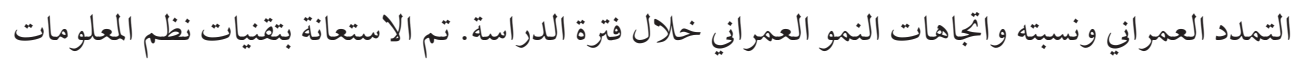
الجغر افية والاستشعار عن بعد، حيث تم استخدام برنابجي (ArcGIS) و (Erdas)، وكذلك تحميل مرئيات (Landsat) و التحليل كالاقتصاص و التحسين و التصنيف و التحرير وغيرها، و كذلك إجراء الحسابات حتى الوصول إلى هينه

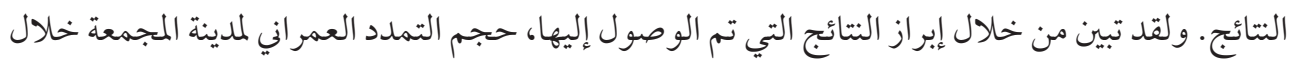

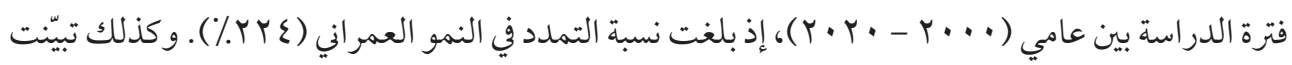
لنا اتجاهات النمو للتمدد العمراني لتلك الفترة، حيث كانت تمتد بشكل ملحوظ للجهة الشرقية والشمالية

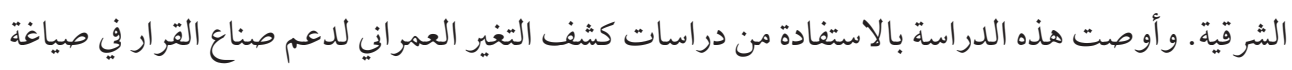

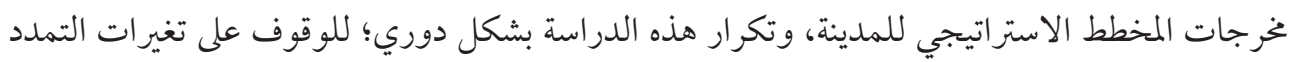

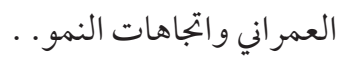
الكلمات المفتاحية: التمدد العمراني، اتجاهات النمو، نظم المعلومات الجغرافية، الاستشعار عن بعد، مرئيات 
بنـاء منـازل، وأسهـمت هـــه التسـهيلات في توسـع

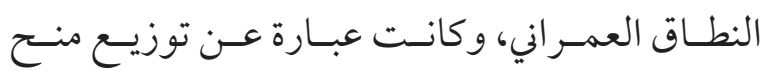
الأراضي وتقديـــم القــــوض الميسّرة.

ويسبرز دور تقنيـات نظمم المعلومـات الجغر افية

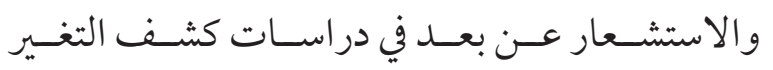

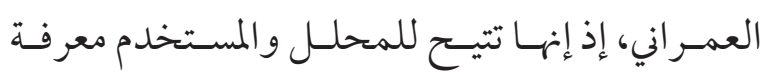

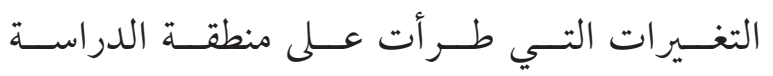

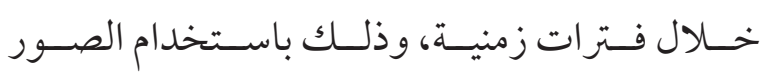

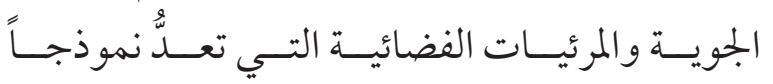

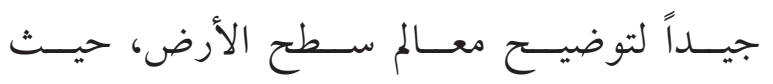

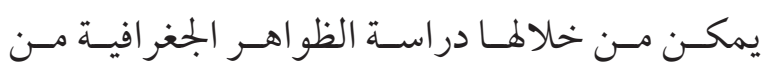

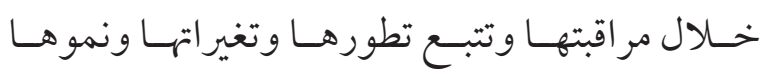

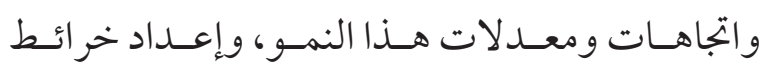

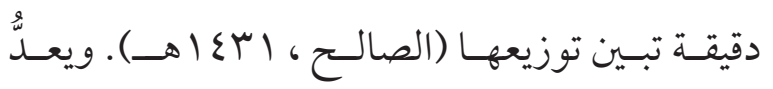

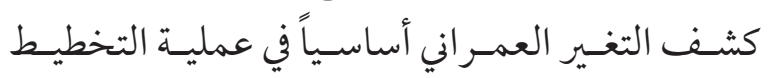

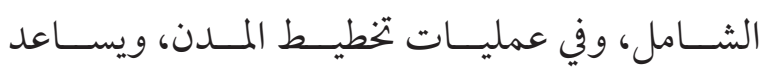

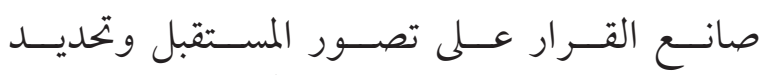

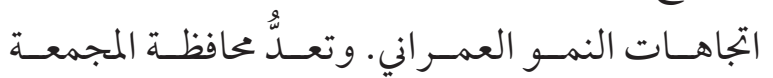

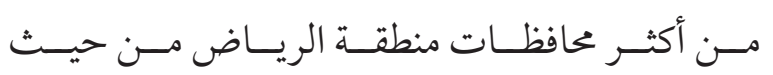

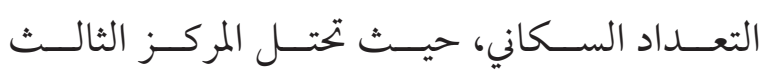

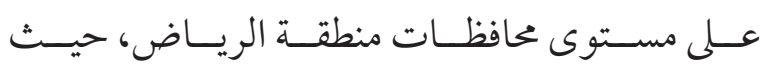

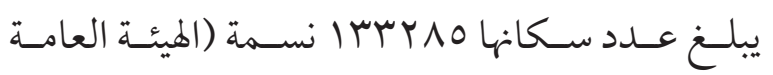

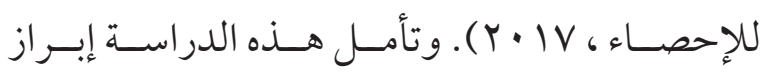

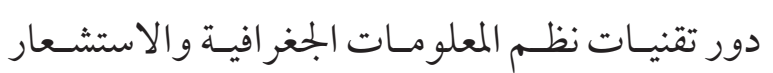

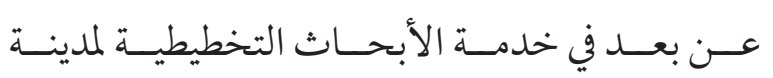

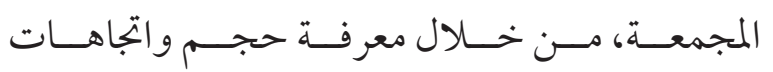

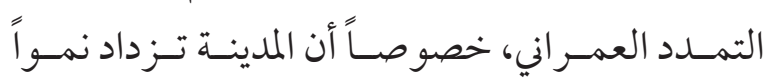

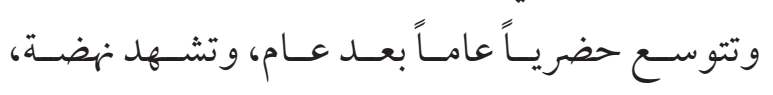

ا

تعـدُّ عمليـة كشـف النمـو أو التمــد العمـــاني

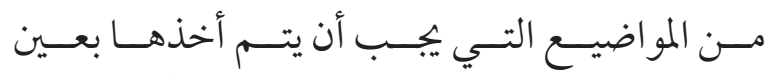

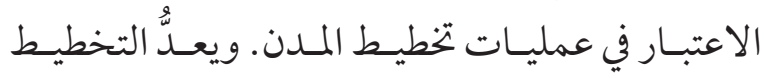

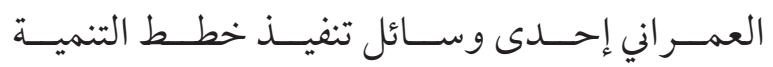

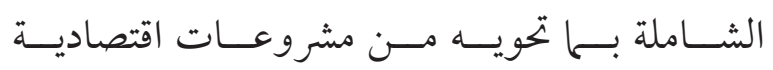

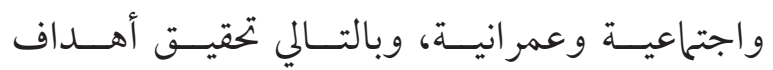

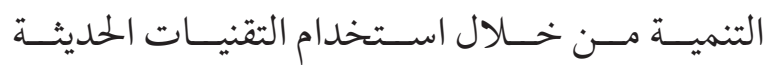

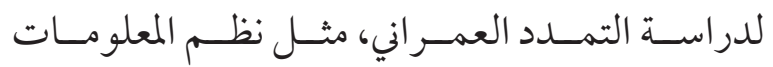

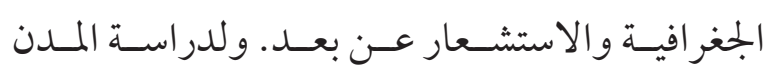

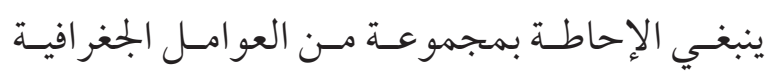

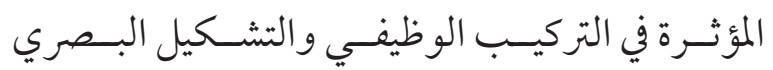

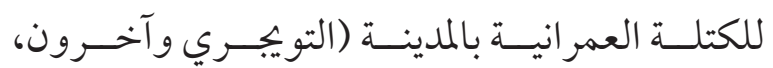
.$(r \cdot) V$

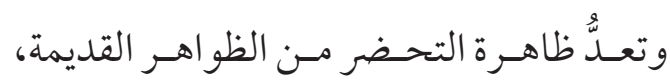

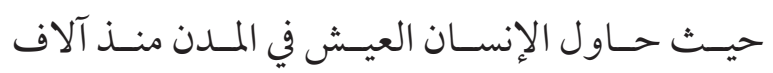

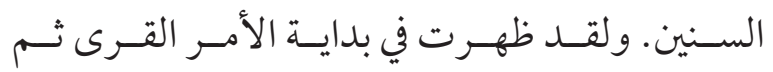

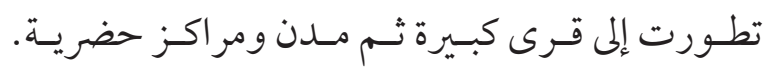

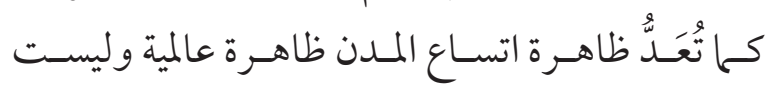

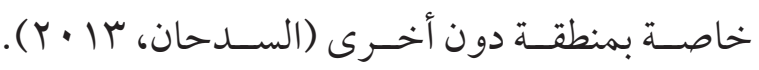

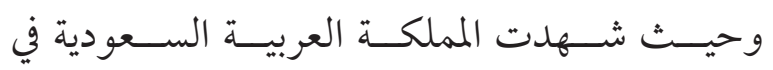

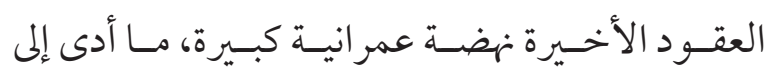

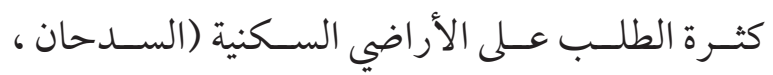

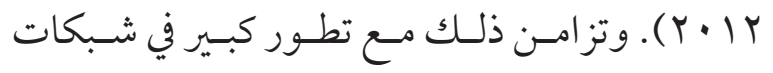

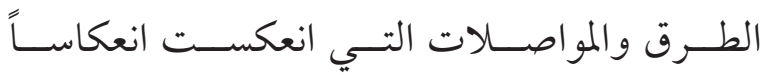

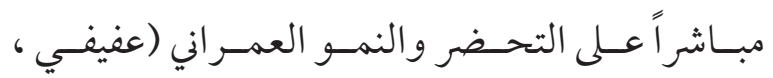

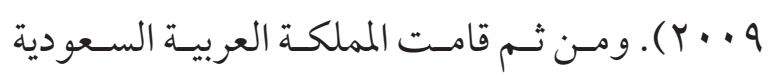

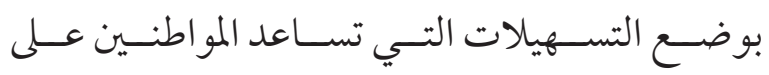


في أكثـــر المـدن غـير قـادرة عـلى التعامـل مـع المشــاكل

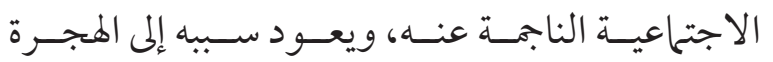

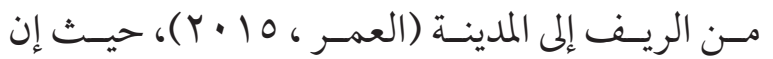

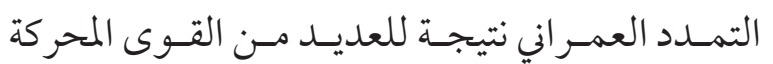

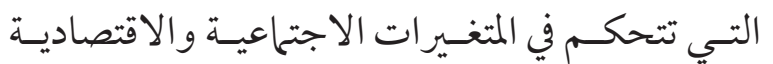

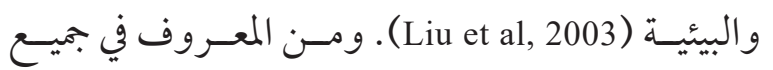

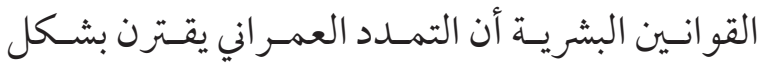

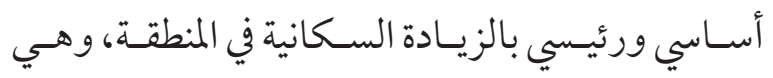

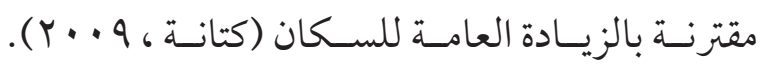

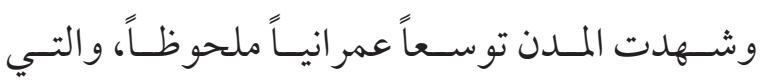

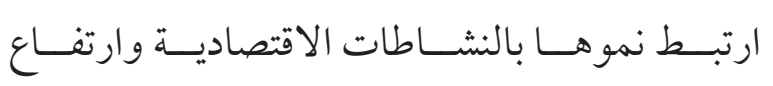

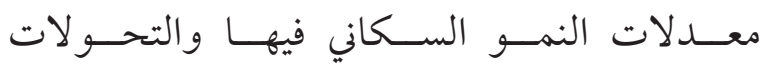

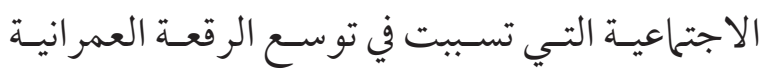

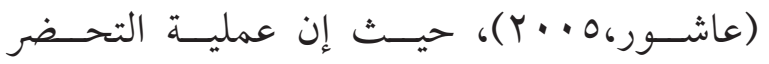

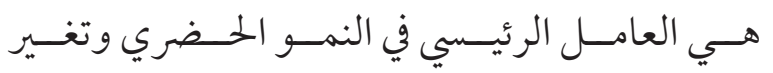

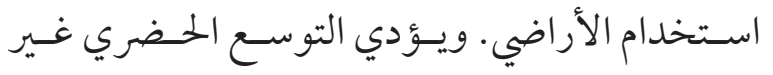

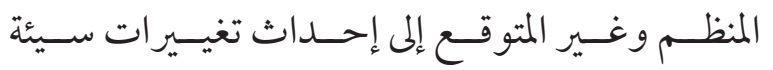

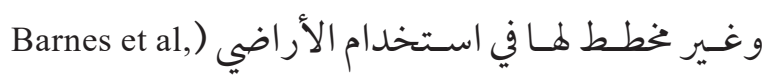

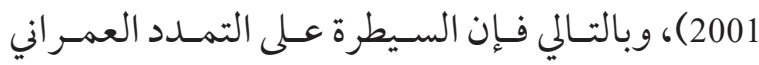
في المســاحات المفتوحسـة تشـكل ضرورة أساسـية فئسية

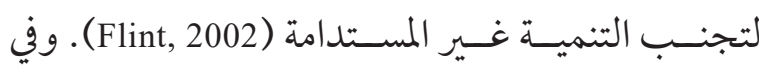

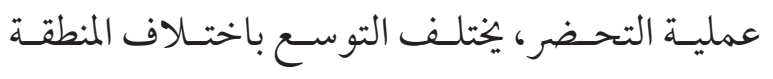

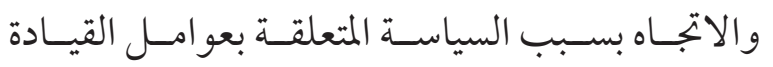

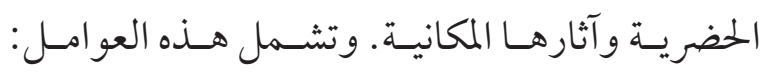

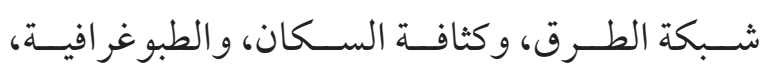

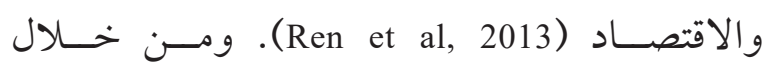

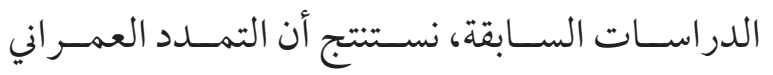

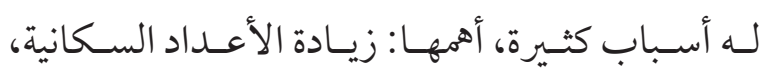

حيــث اسـتقطبت الكثــير مــن المشــاريع الرائــدة

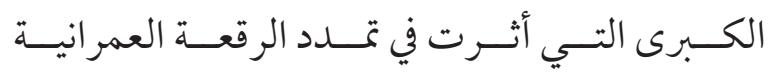

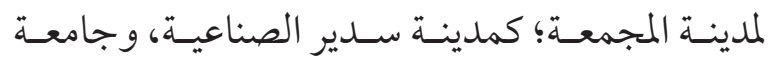

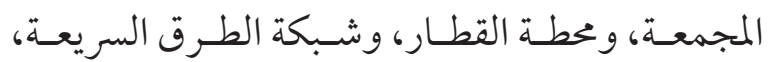

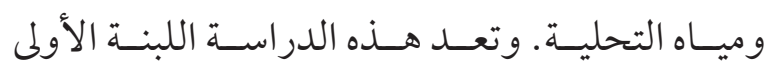

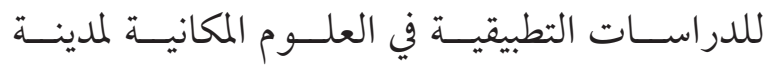

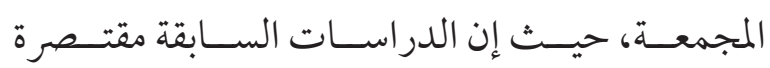
عسلى الدراســات النظريــة.

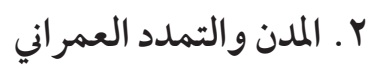

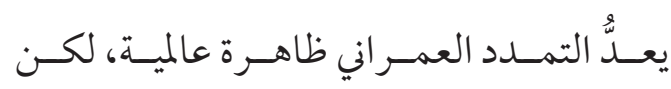

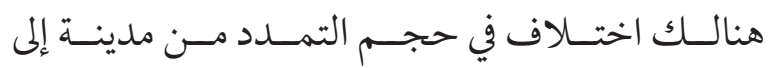

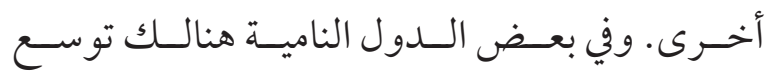

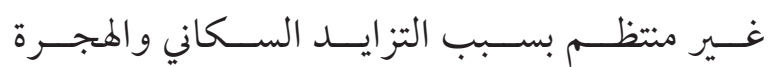

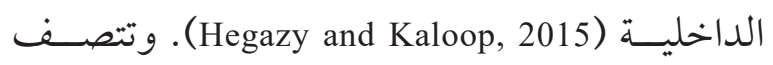
ظاهــرة اتســاع المــدن، خاصــة في المملكـــة العربيـة السـعودية، بخصائص جعلتهـا تختلـف عـن غيرهـا،

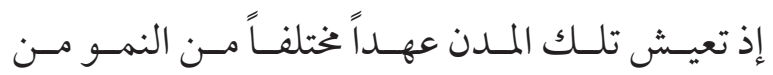

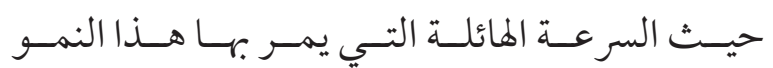

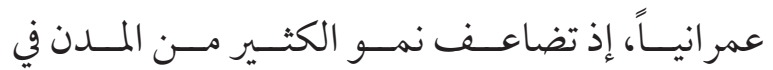

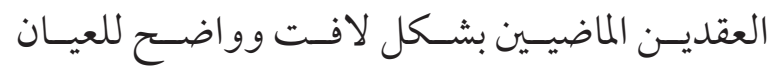

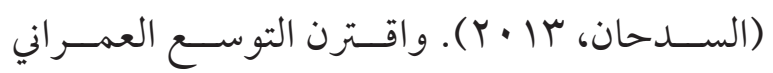

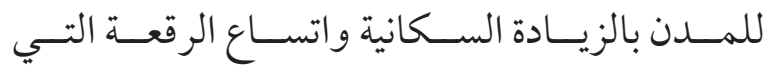

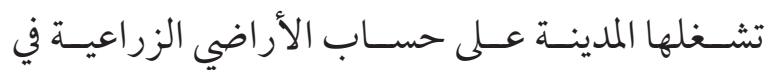

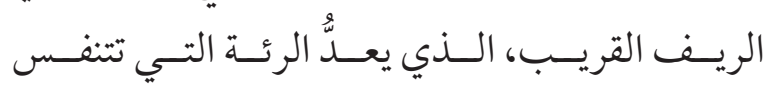

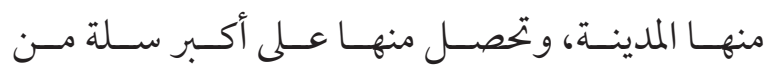

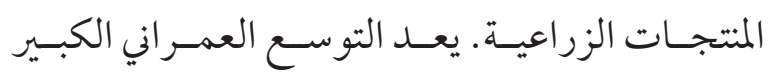

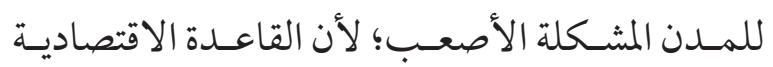




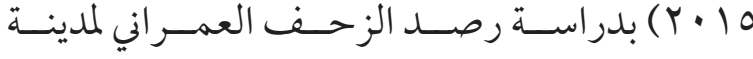

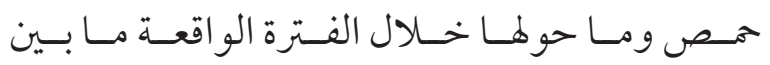

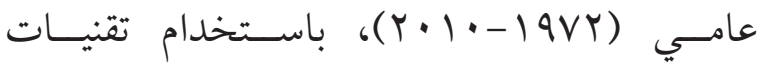

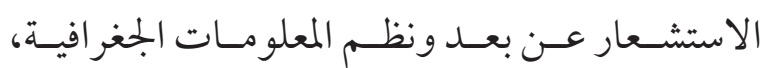

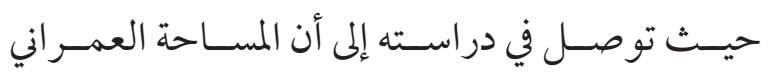

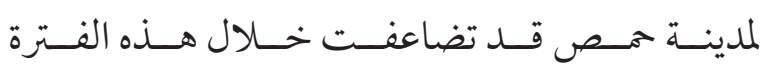

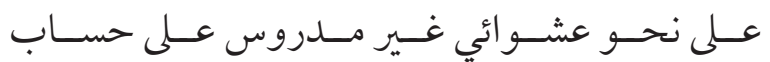

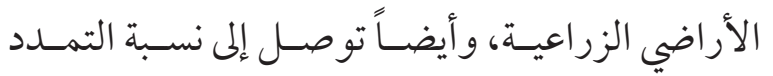

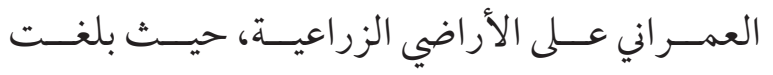

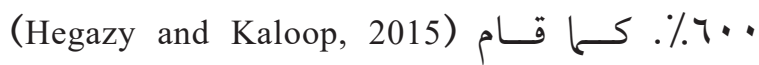
بتقيــم اكتشـاف تغيـير اسـتخدام الأراضي باسـتخدام

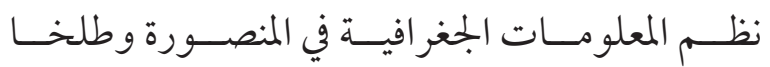
التابعـة لمحافظــة الدقهليـة بمــصر مـن عـام 1910

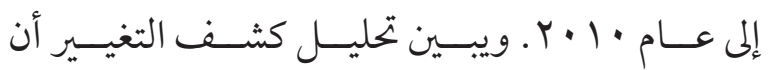

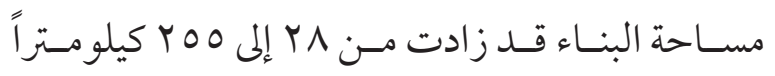

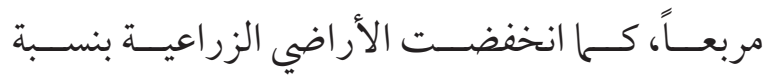

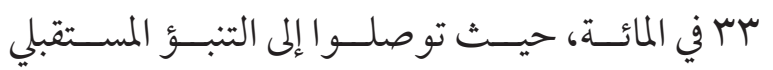
باسـتخدام تحليـل سلســلة ماركـوف فـ وأيضــاً قـام

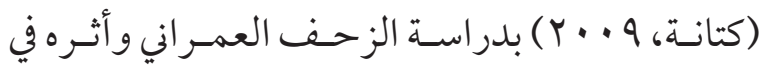

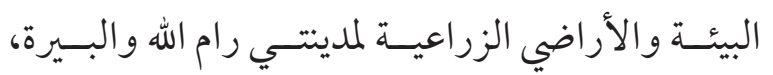
باسـتخدام نظـم المعلو مـات الجغر افيـة و الاستشـعار

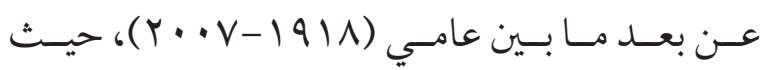
توصلـت الدراسـة إلى أن للاحتــلال الإسر ائيسلي دوراً

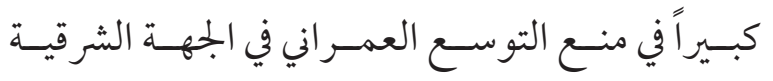

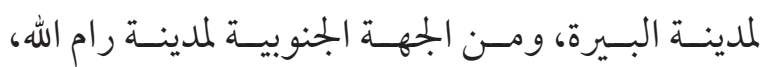

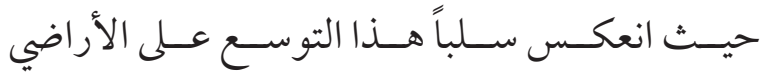
الزراعيـة و الرعويــة. وحيــث تو صلــت الدراســة إلى نســبة زيــادة المســاحة العمر انيــة لمدينتـي رام الله

$$
\text { و النمــو الاقتصــادي للمدينـة. }
$$

r. تقنيات نظم المعلومات الجغر افية والاستشعار عن بعد في العمران

تلعب تقنيات نظـــــم المعلو مــــات الجغخر افيـــة

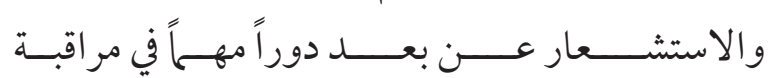

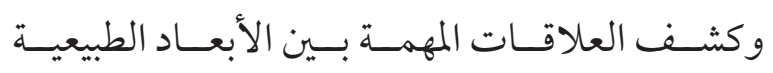

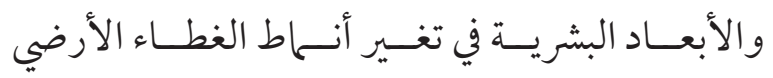
واسـتعمالاته، وإســهامها في تحديـــد موقــع واتجــاه

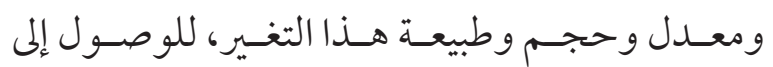

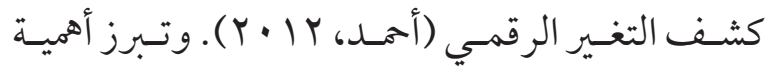
تطبيقـات نظـم المعلو مــات الجغر افيـة و الاستشـعار

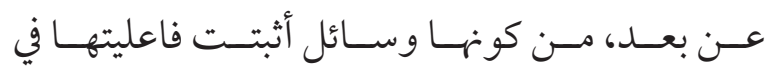

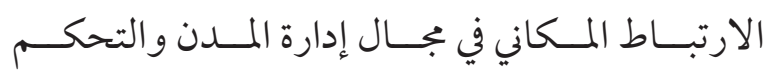

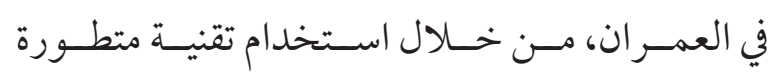

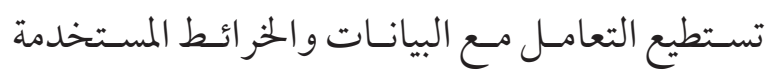

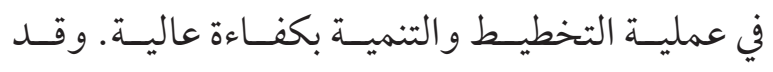

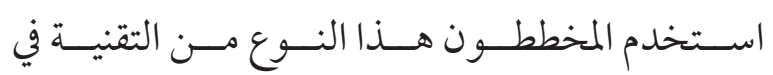

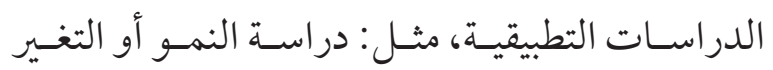

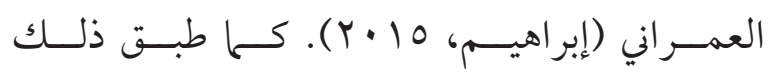

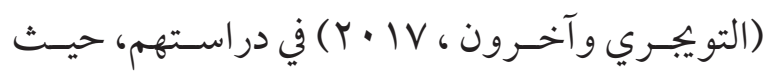

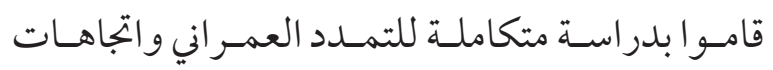

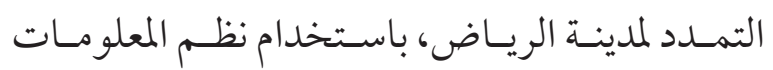

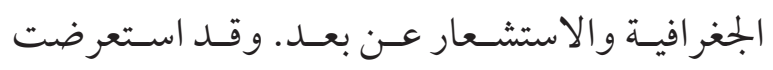

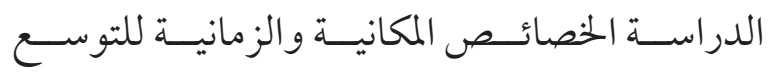

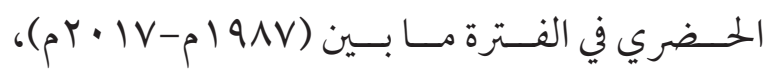

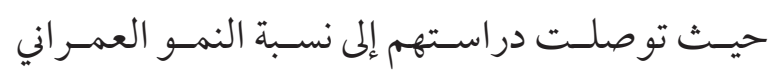

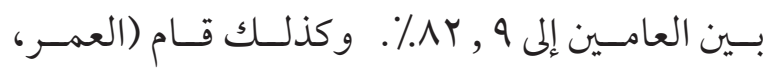


التمــدد العمــراني مــع هـــه الدراسـة في تحليـل التمدد

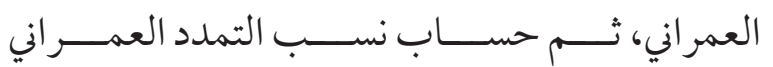
واتجاهاتــــهـ في مدينــة المجمعة باســـتخدام تقنيــات

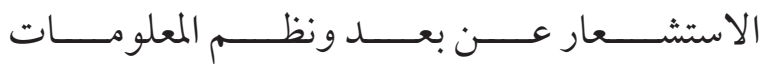

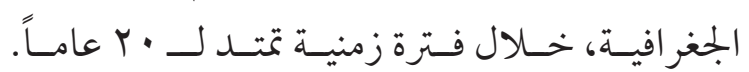

\section{ع. منطقة الدراسة}

مدينــة المجمعــة تقــع في شـــال منطقــة

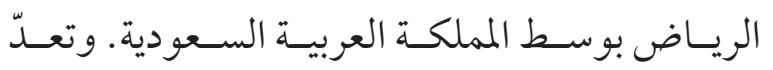

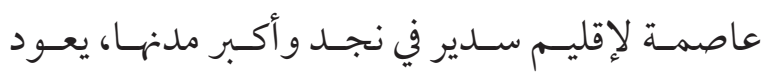

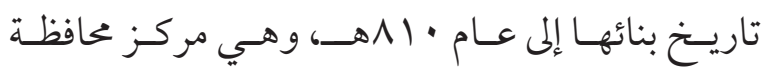

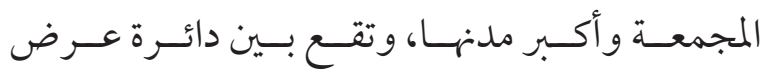

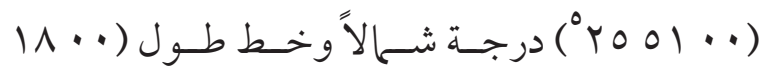

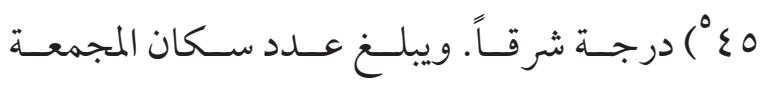
نحسو

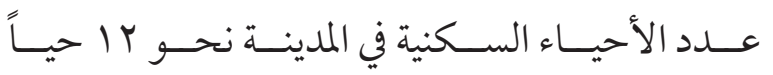

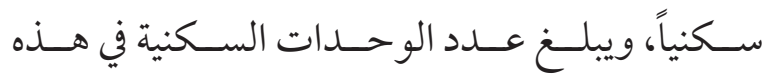

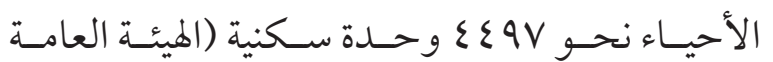

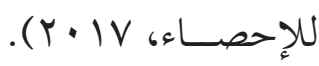

\section{هـ المنهجية العلمية}

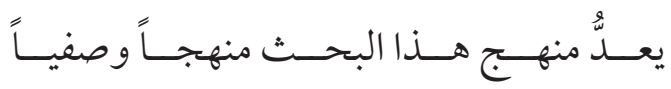

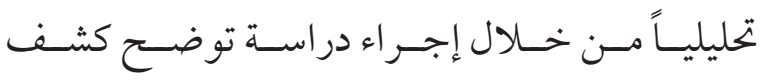

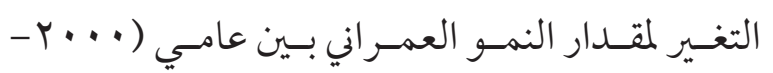

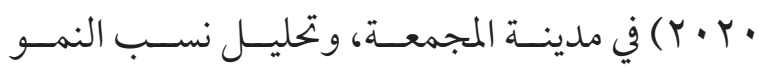

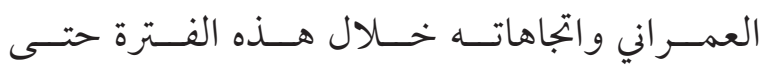

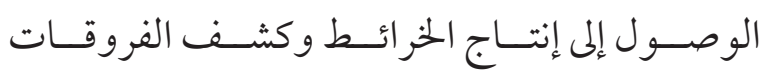

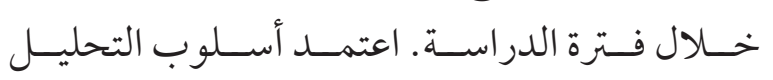

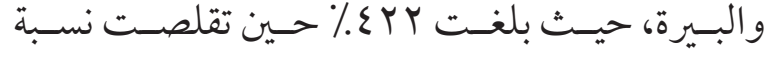

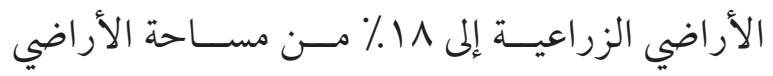

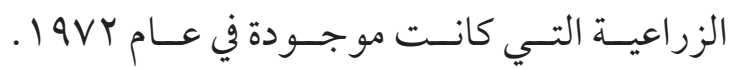
وقــد وفــرت تقنيــات نظـــم المعلومـــات

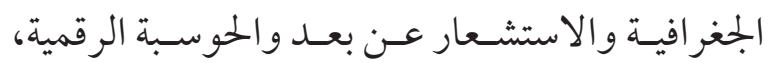
أدوات للتعامــل مــع النـــاذج الحضريـــة الرياضيــة

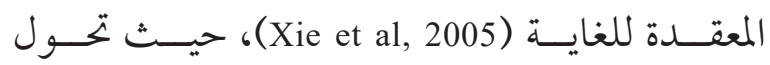

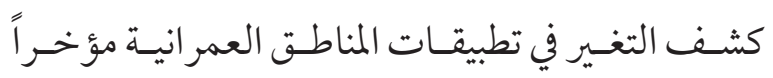
مـن الاكتشـاف الأسـاسي إلى قيـاس الأنـاط، وتحليل

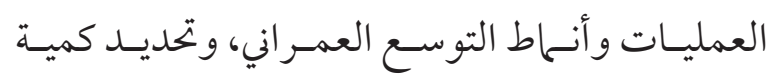

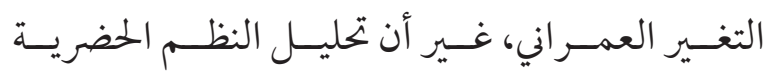

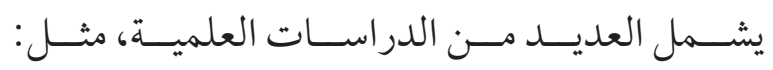

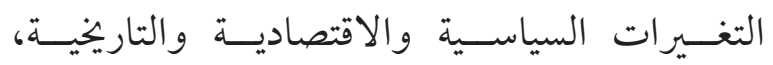

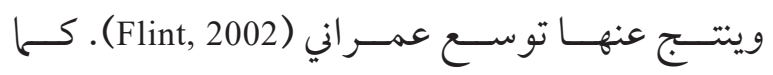

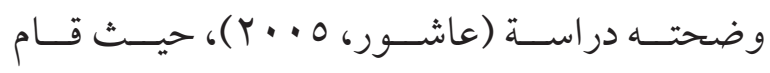

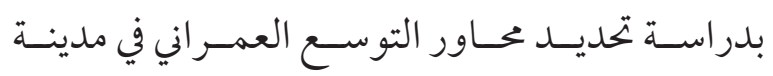

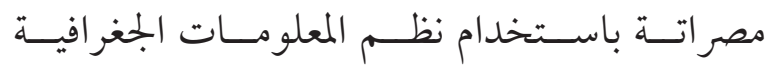
و الاستشـعار عـن بعـد، مسـتعيناً بالمرئيـات الفضائيـة

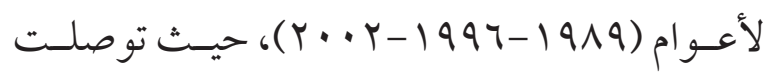

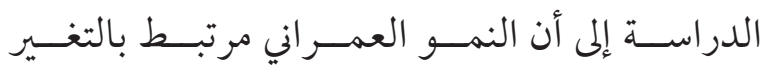

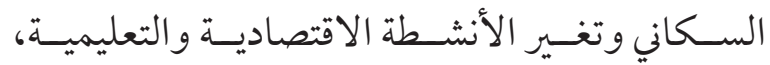

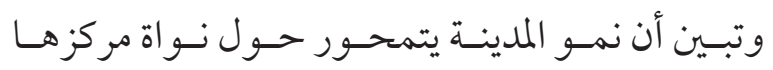

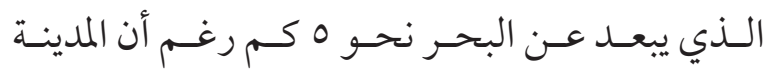
سـاحلية.

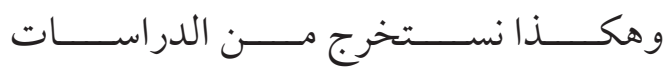

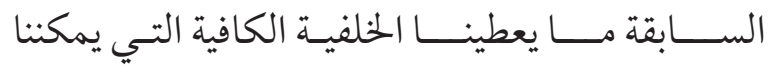

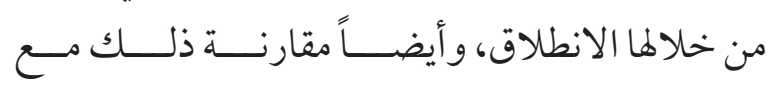

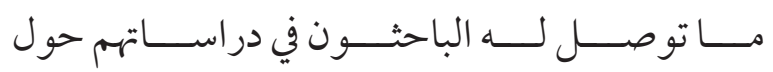




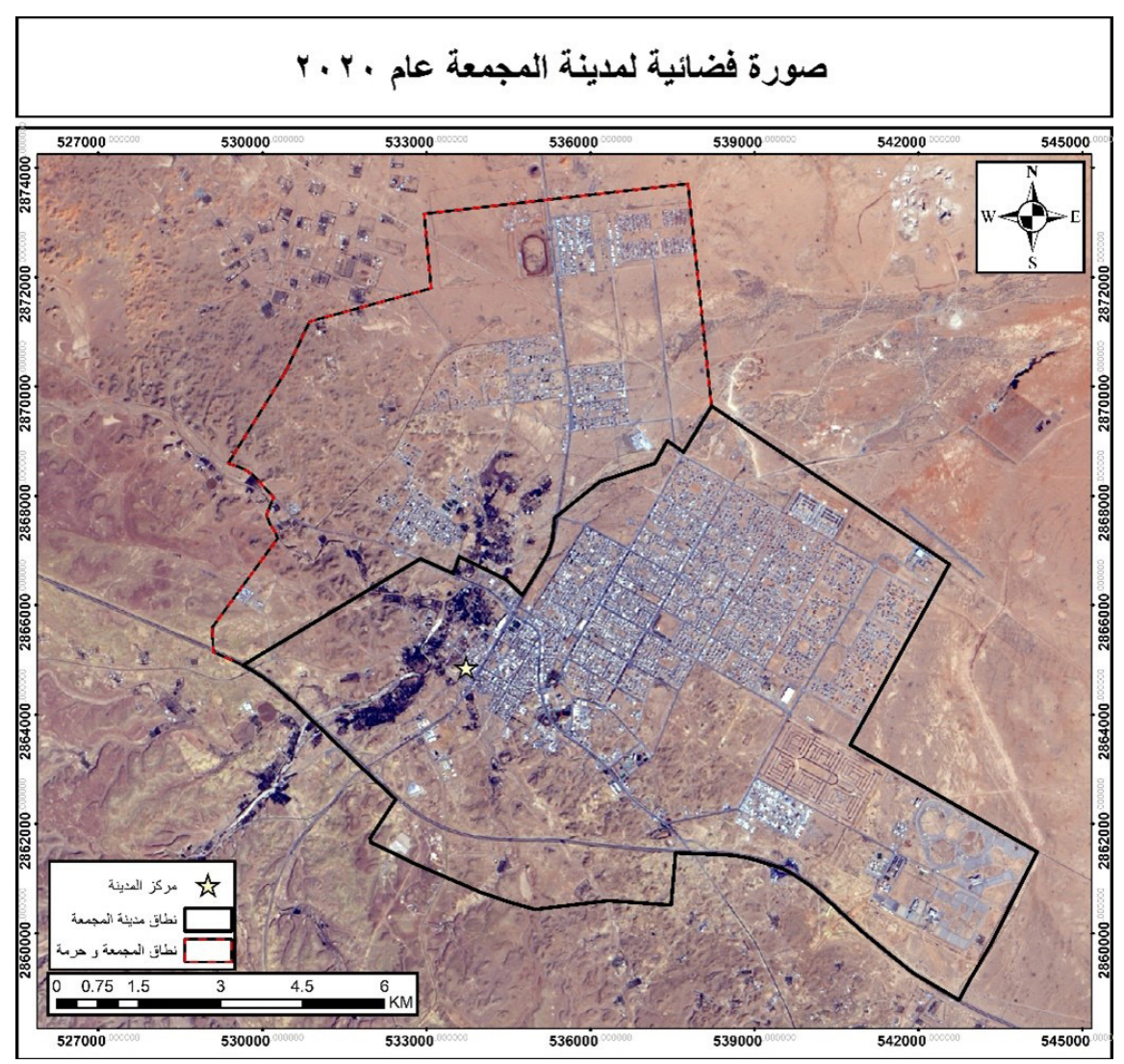

الشكل رقم (1) الـورة فضائية حديثة لمدينة المجمعة في وضعها الر اهن، المصدر: USG

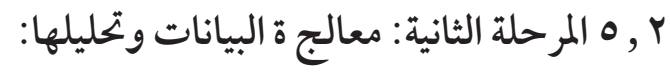

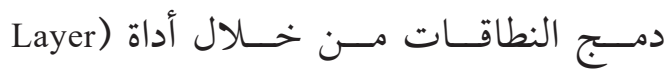

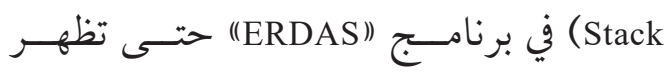

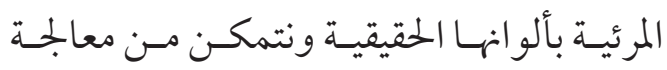
المرئيسة.

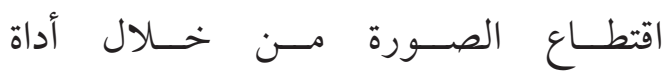

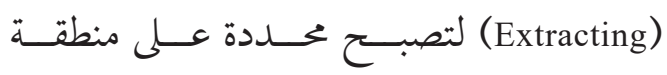

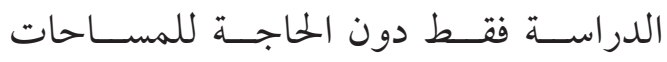

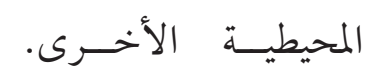

زيــادة درجـة وضـوح صـورة القمـر الصناعي

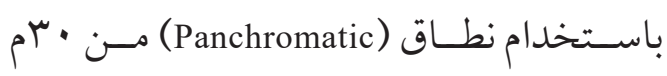

في هــا البحــث عـلى ثـلاث مراحـل رئيسـية، هـي

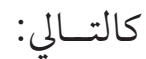

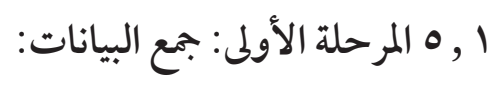

تسم جمـع البيانـات عـبر كل مـن هيئسة المسـاحة

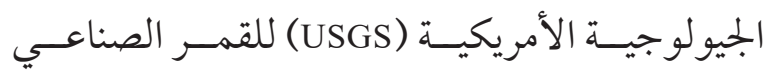
(LANDSAT 7,8)

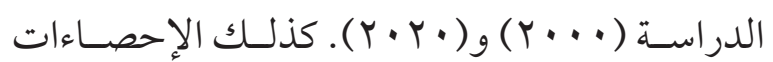

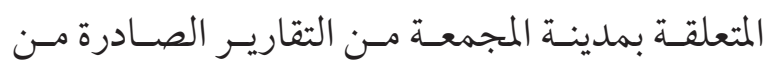

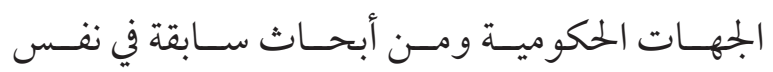

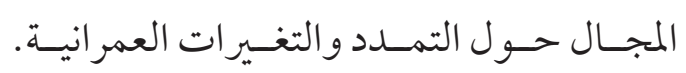


النمـــو العمـــراني في مدينــة المجمعــة. ومسـن خــلال

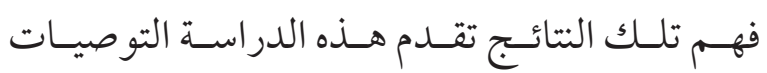
الملائمسـة لإدارة المدينـة في المسـتقبل.

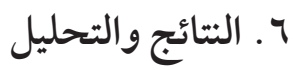

ا , التطور التاريخي للنمو العمراني:

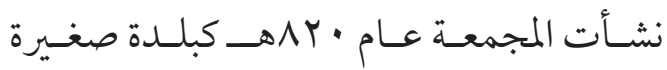

عـلى ضفـاف وادي مشـقر وروافـده، تحدهــا المـزارع

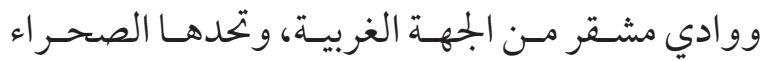

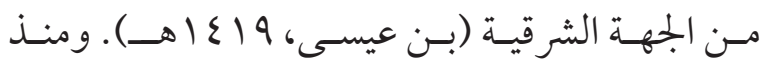

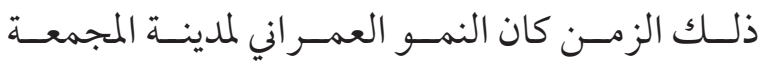

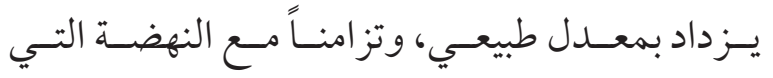

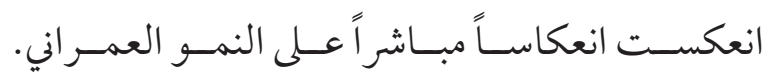
ومدينـة المجمعــة تقــع في موقــع اسـتراتيجي حيـث

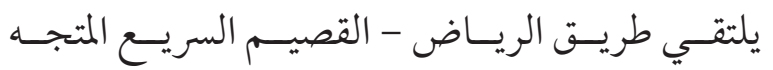

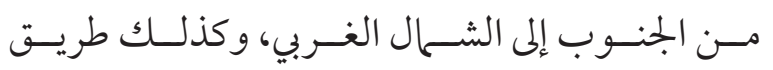

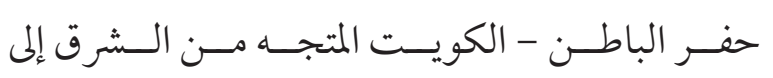

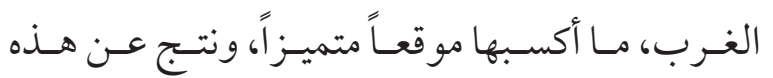

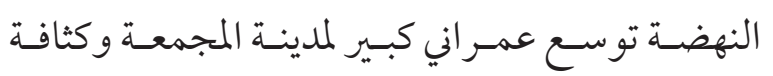

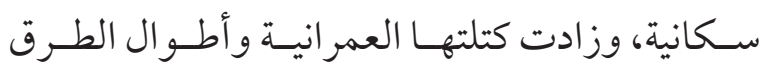
منــذ ذلـك الوقـت حتـى وقتنـا الحـالي.

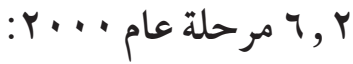

أقـــب إحصائيــة هـــذا العــام كانــت عــام

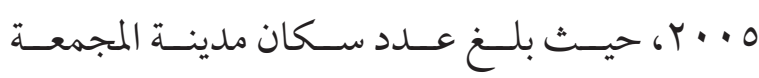
نحـو (9VV) (1) نسـمة (وزارة الاقتصـاد و التخطيط،

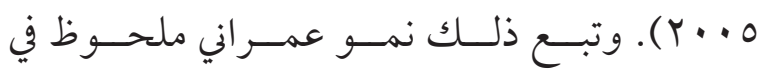

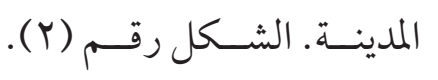

إلى 0 ام لإظهـــار تفاصيــل الظو اهـــر بشـكل

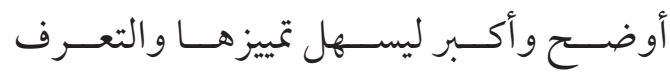
إليهــا بصريـاً.

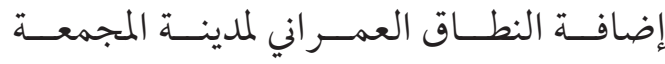
وحر مــة المعتمــد مـن وزارة الشـؤون البلديــة و القرويـة، وفصـل نطـاق حرمـة عـن المجمعة لحسبـاب المســاحات الخاصـة لمدينـة المجمعــة.

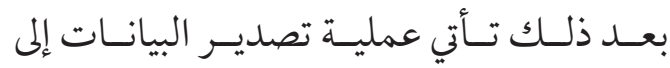

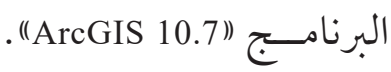

Supervised Clas- عمليـة التصنيـف المراقـب (sification بعــد الرقميــة إلى خريطــة موضو عيــة يمكــن

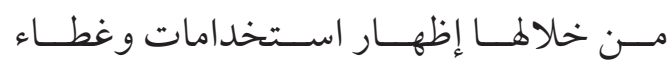

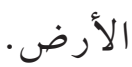
تحويــل البيانـات الخاصــة بمنطقــة الدراســة

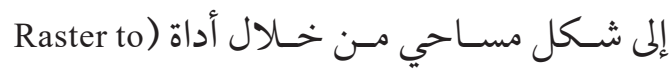
(Polygon أو حجـــم الكتلـة العمر انيـة. قيـاس اتجاهـات النمــو لمنطقـة الدراسـة مـن مركـز المدينـة التاريخـي.

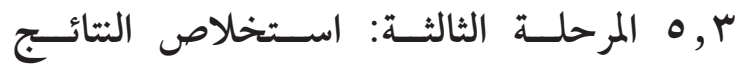

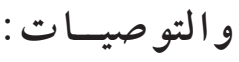
يتـــم اسـتعر اض نتائسج وتحليـل الدراسـة مــن

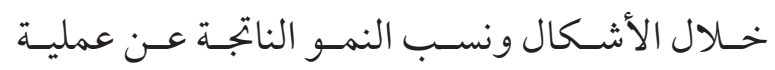
التحليـلـ، وربطهــا بالدراســات الســابقة، وتحليـل

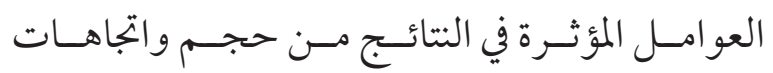




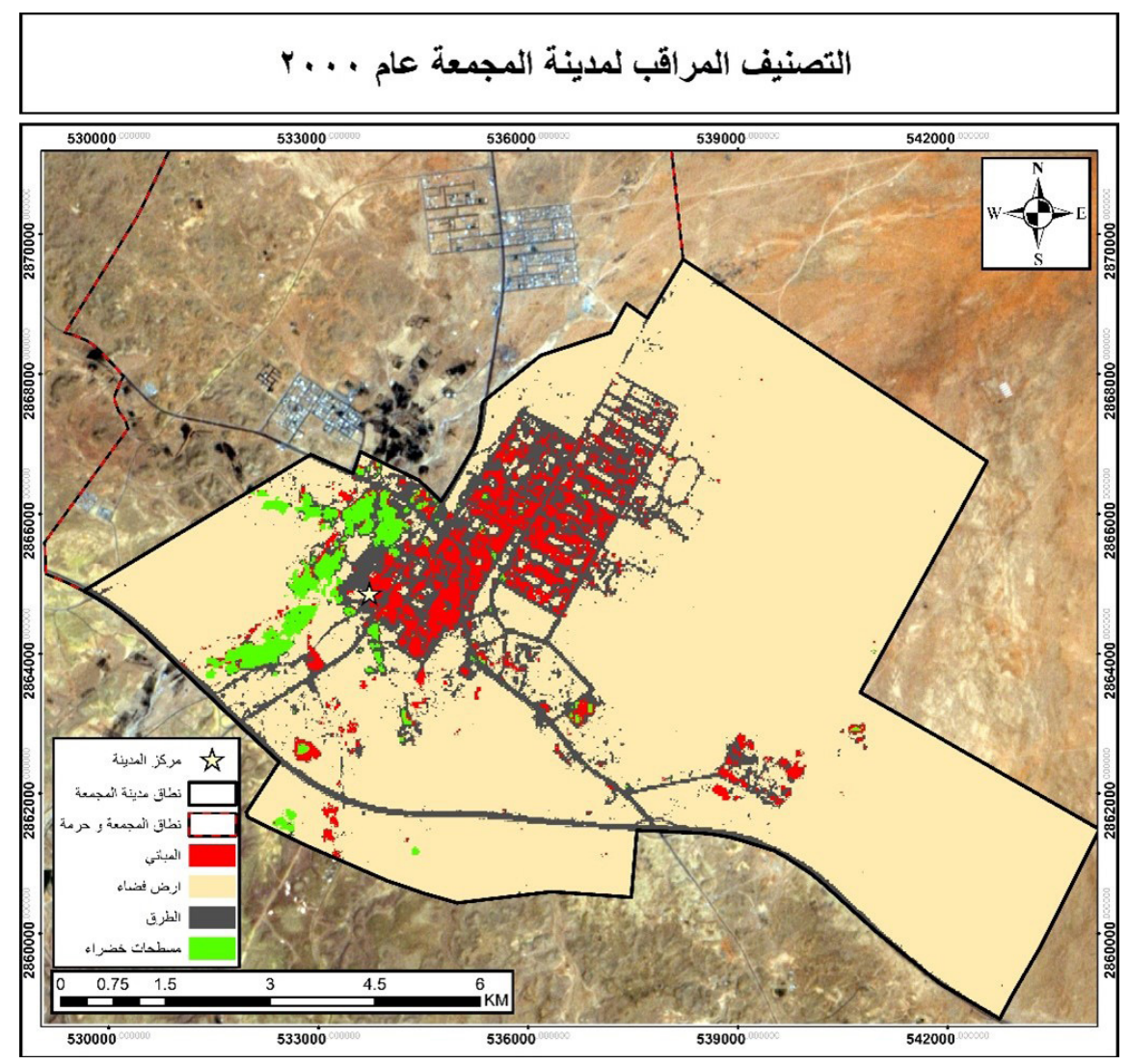

الشكل رقم (Y) . خريطة تصنيف مر اقب لمدينة المجمعة عام ....

بالكيلو مثر المربع

60.5

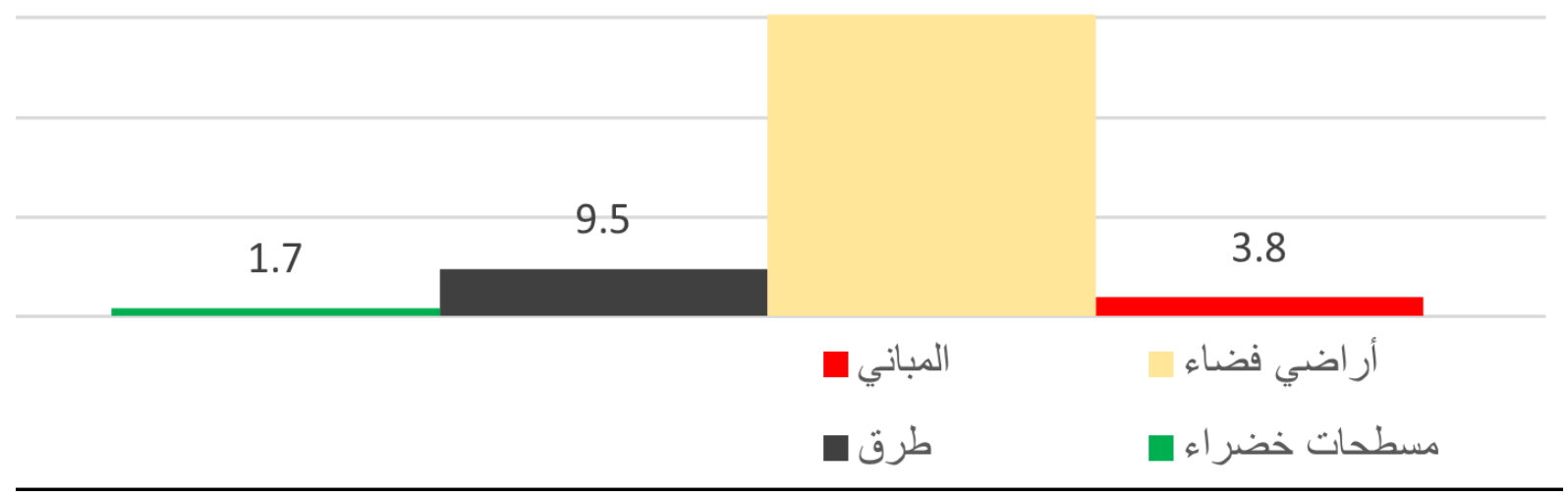

الشكل رقم (r) . رسم بياني يوضح مساحات التصنيف لمدينة المجمعة عام .... 


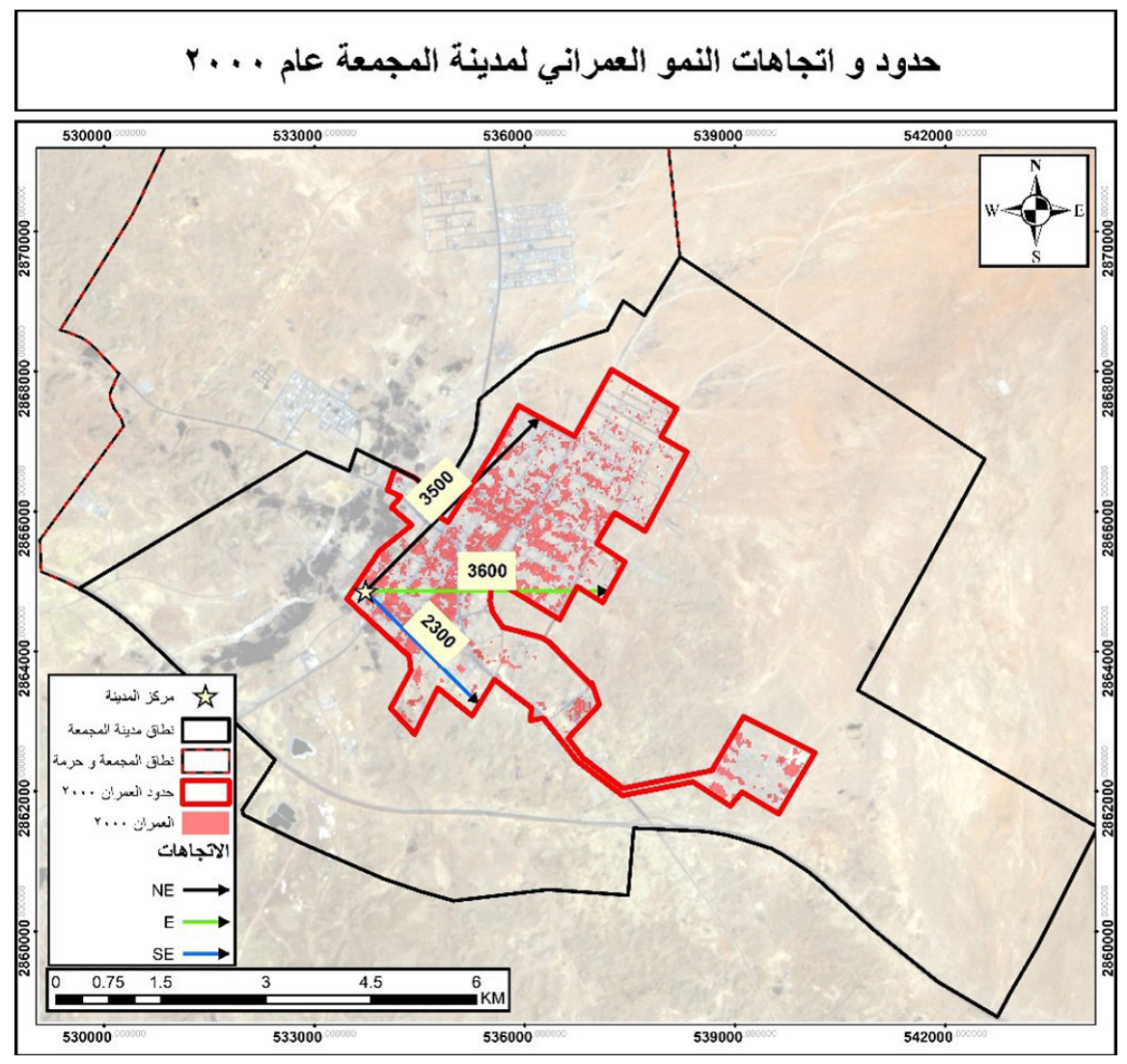

الشكل رقم (ع ). حدود واتجاهات النمو العمر اني لمدينة المجمعة عام ...

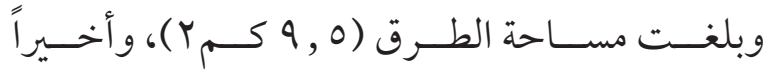

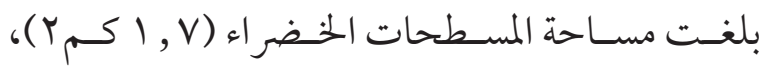
كــا في الرســم البيـاني الشــكل رقــم (ب). فمـن خـالال خريطـة حــدود و اتجاهـات النمـو العمــراني لمدينـة المجمعـة لعـام ( (... ب ) الشـكل رقم

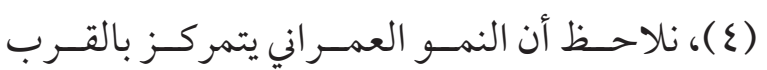

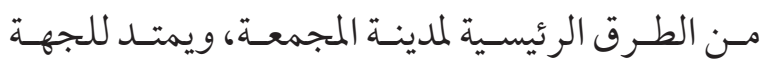

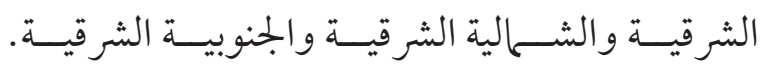

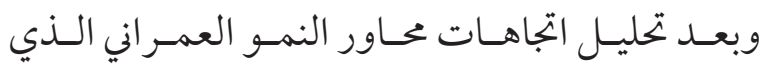

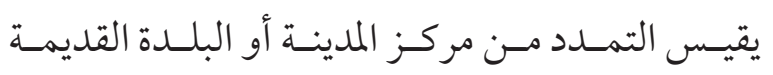

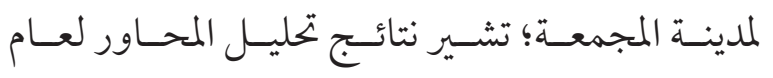

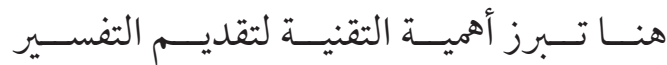

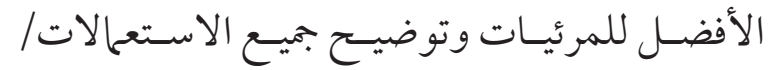

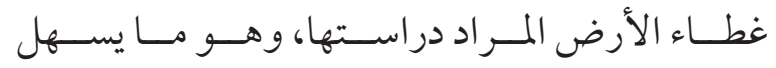

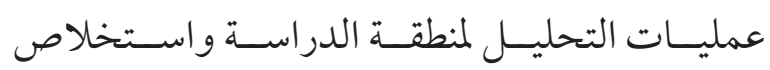

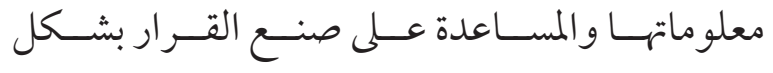

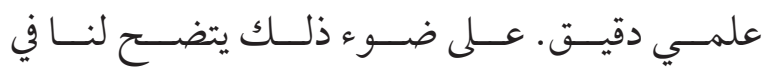

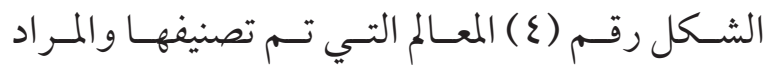
معرفتهــا واســتخراجها (المبــاني، الطـــرق، أراضٍ

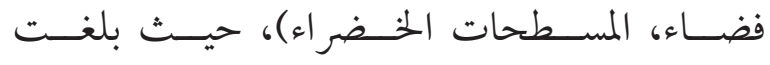

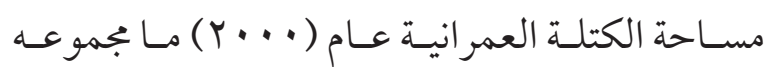

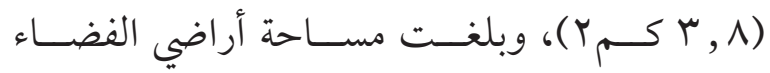

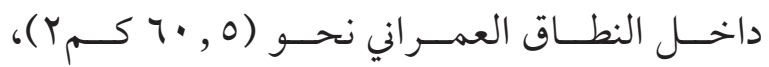




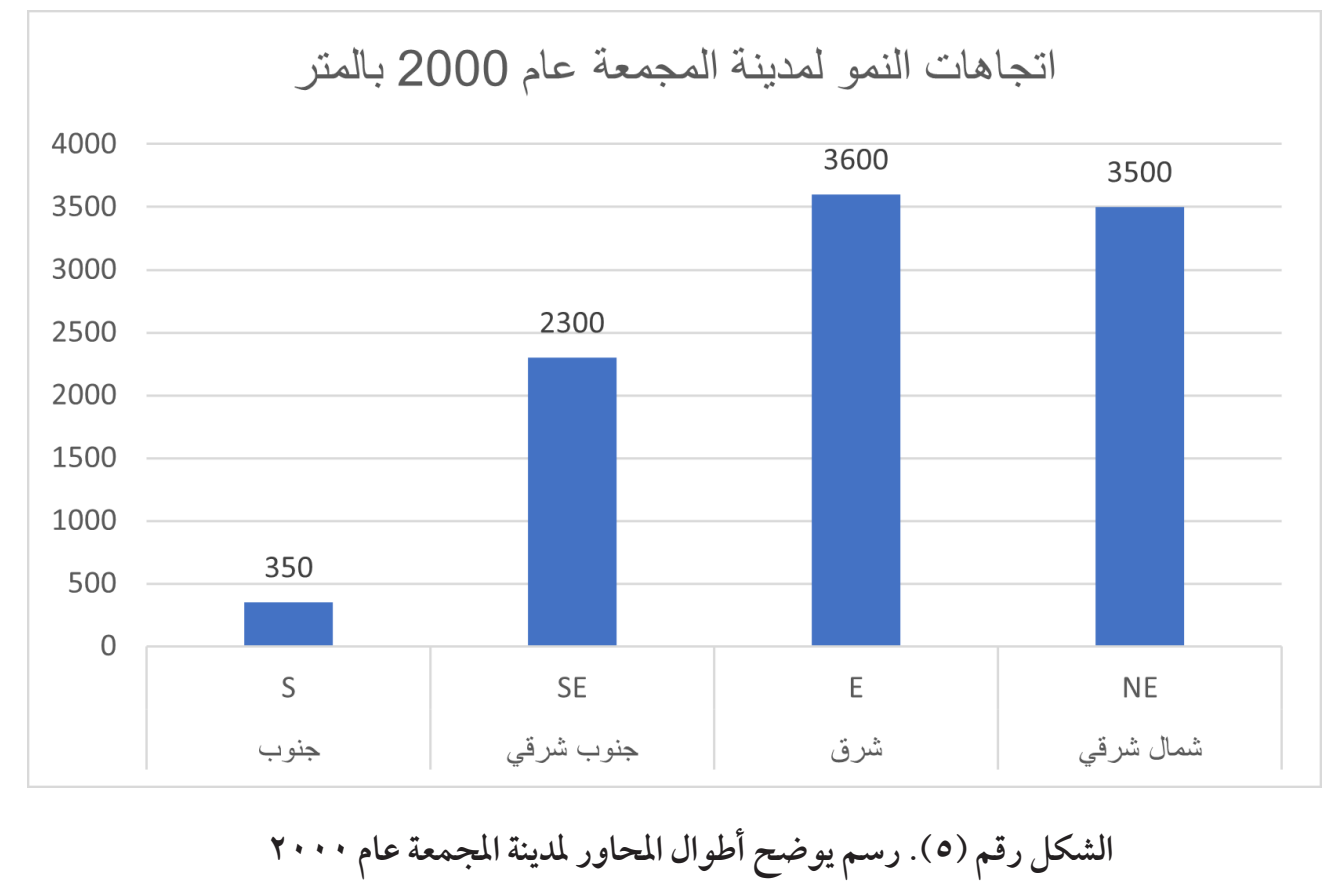

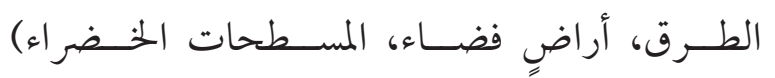

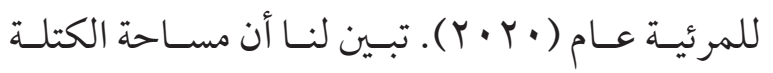

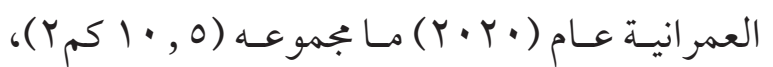

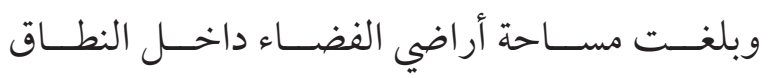

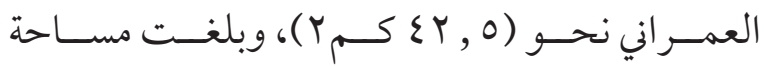

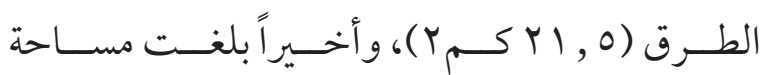

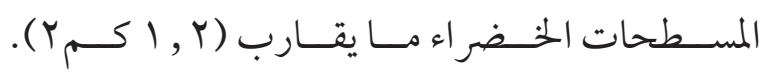

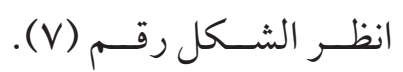
ومسن خـلال خريطـة حسدود واتجاهـات النمو

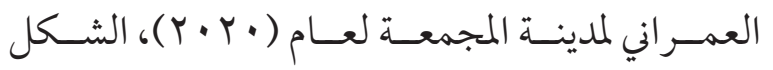

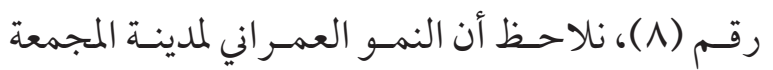

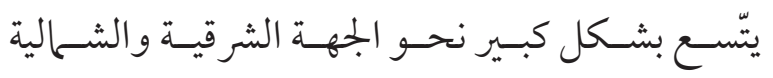
الشرقيـة والجنوبيـة الشرقيـة، وأيضـاً الجهــة الجنوبيـة.

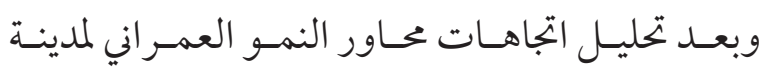

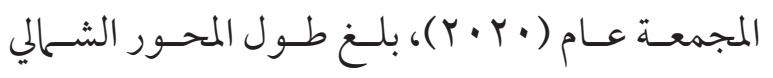

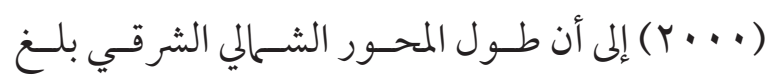

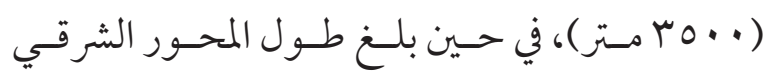

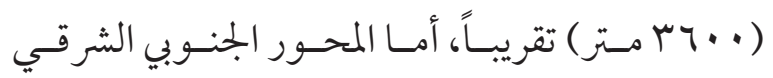
فـكان طولـه ( . . سب مـتر) . الشـكل رقـم (0).

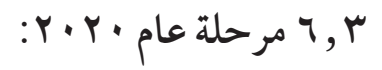

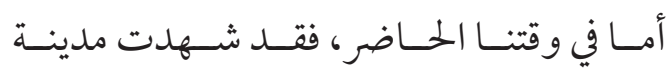

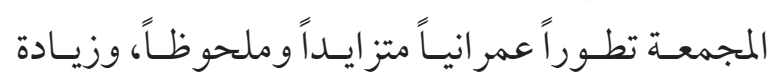
في عـدد السـكان، حيـث بلغــت في أحســث إحصائيـة

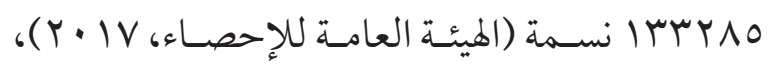

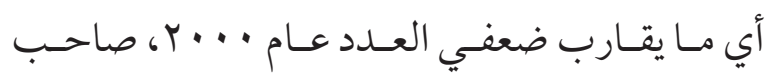

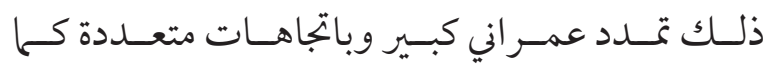
هــو ملاحـظظ في الشـكل رقـم (7). بعــــ أن قمنــا بتوضيـــح المعــالم التـي تـــم

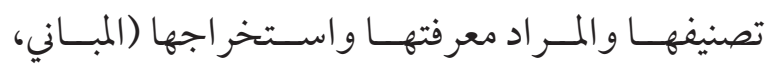




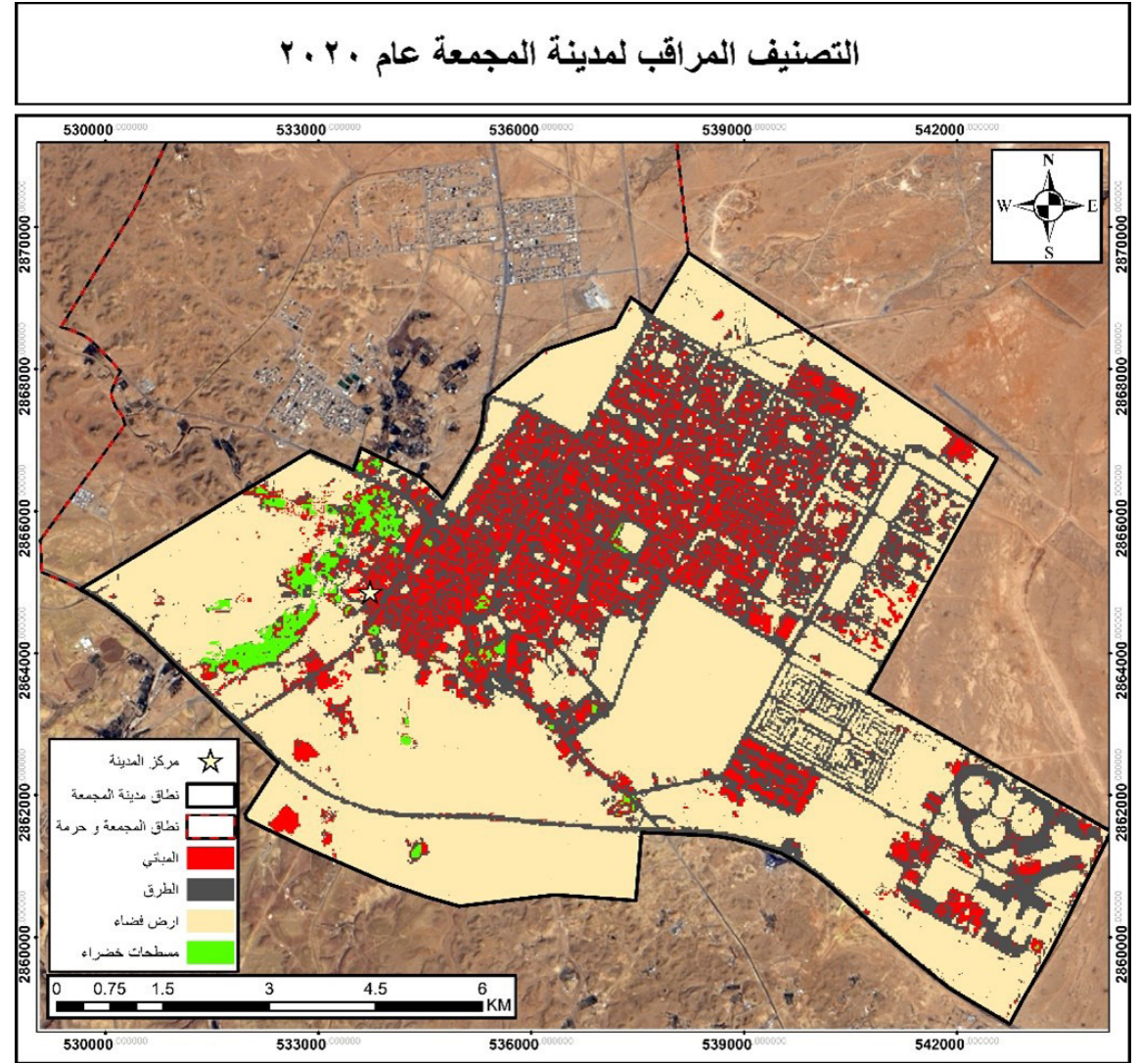

r. الشكل رقم (7 ) . خريطة تصنيف مر اقب لمدينة المجمعة عام

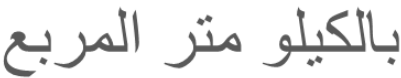

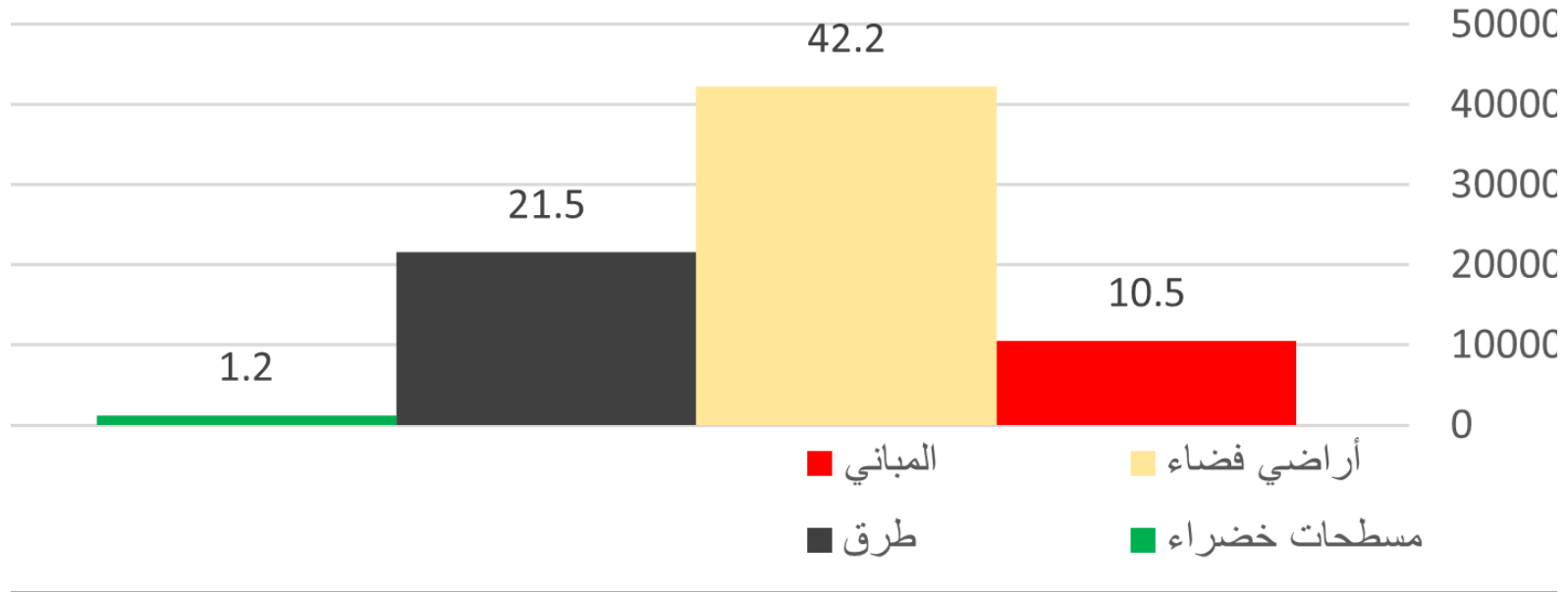

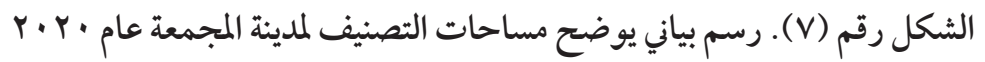




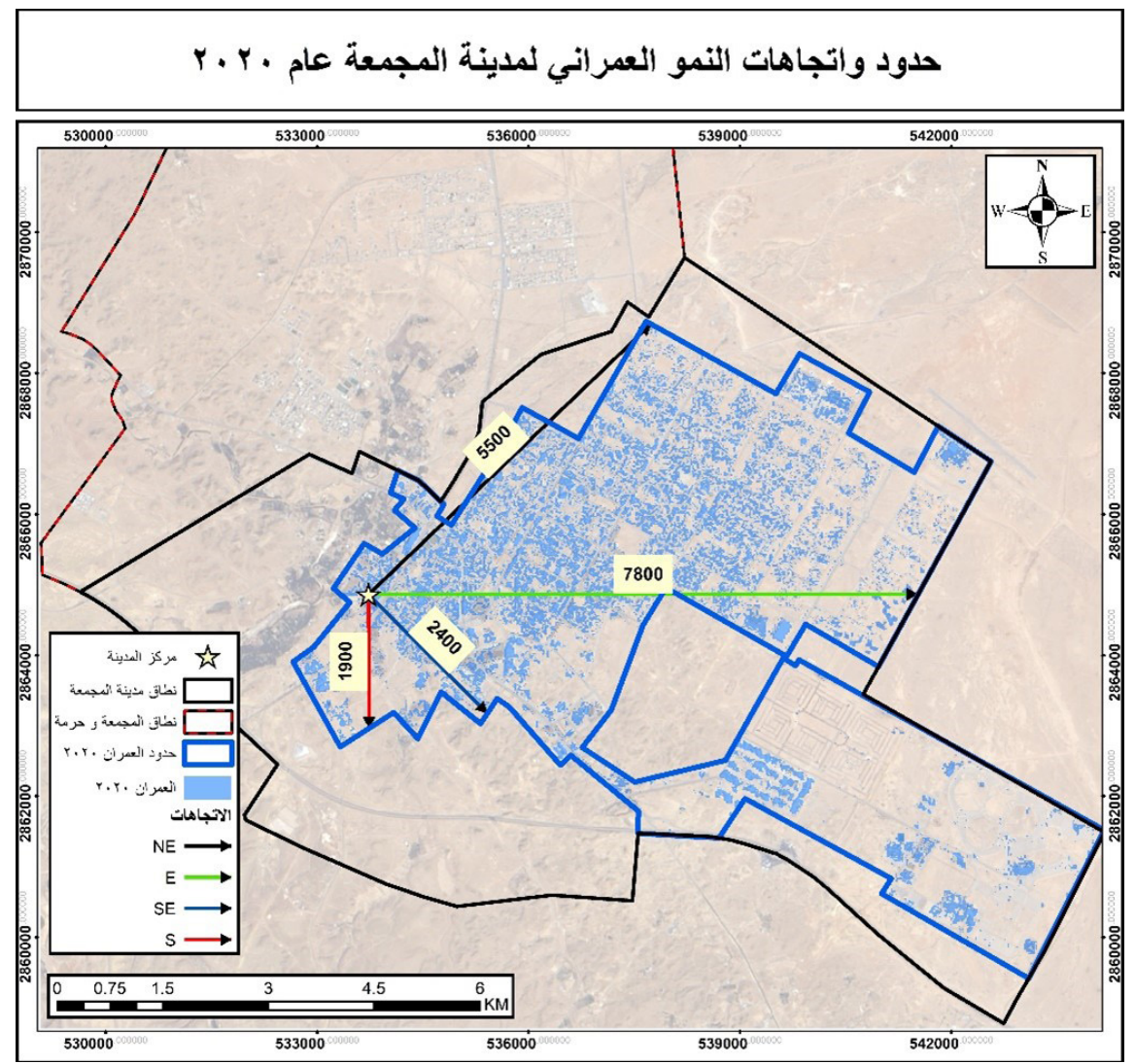

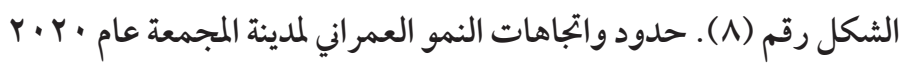

اتجاهات النمو لددينة الدجمعة عام 2020 بالمتر

\begin{tabular}{|c|c|c|c|c|}
\hline \multicolumn{4}{|c|}{7800} & \multirow{3}{*}{$\begin{array}{l}6000 \\
4000\end{array}$} \\
\hline & & & 5500 & \\
\hline 1900 & 2400 & & & \\
\hline$S$ & $\mathrm{SE}$ & $E$ & NE & \\
\hline جنوب & جنوب شرقي & شرق & شمال شرقي & \\
\hline
\end{tabular}

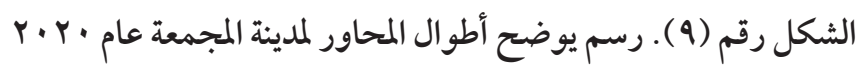


حيـث أثبــت التحليـل السـابق لـكلا المرئيتـين

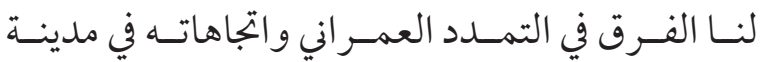

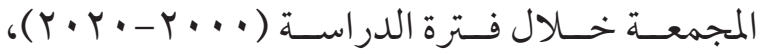

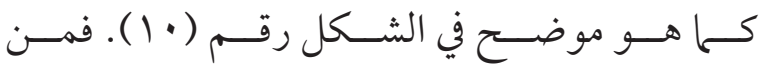

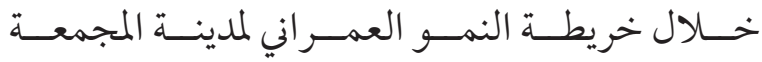

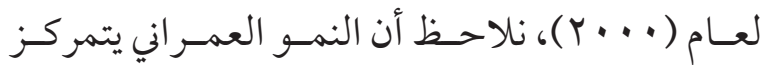

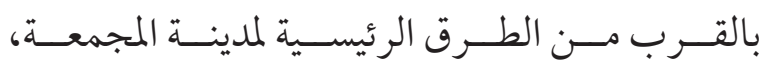

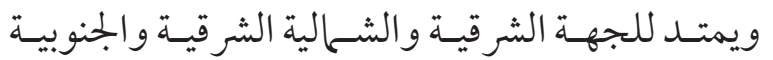

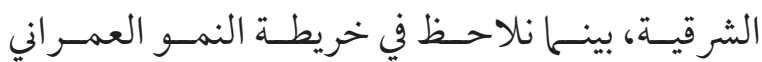

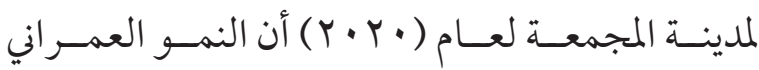

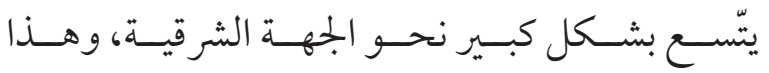

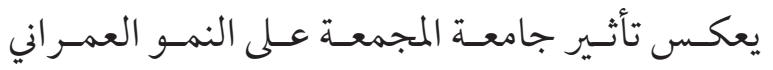

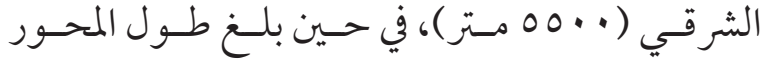

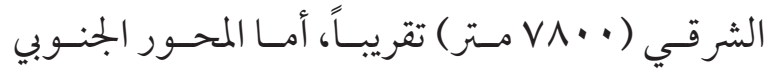

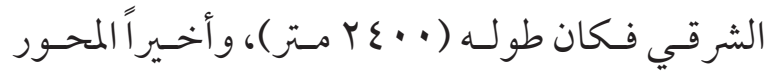

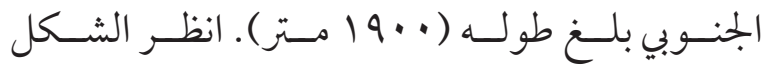
(9) - (9) - (9)

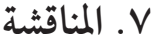

نسـتعرض هنــا النتائســج التـي توصلــت

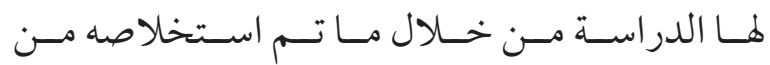

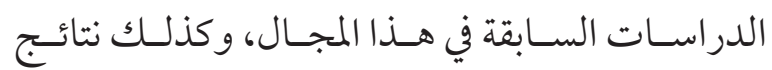

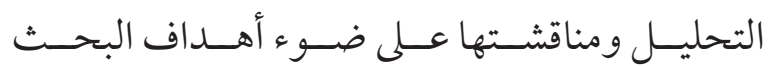
المذكـــورة مســبقاً.

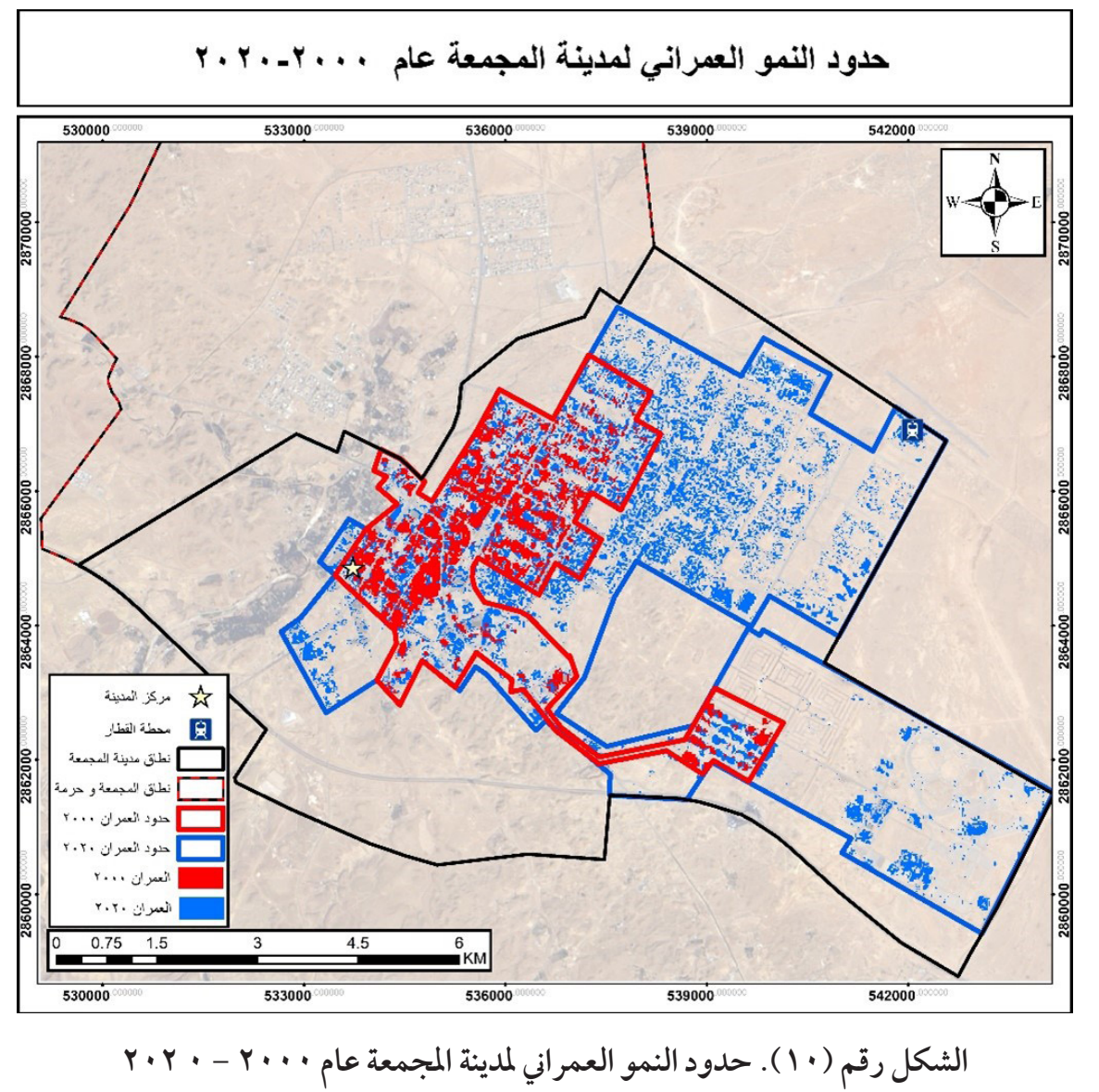




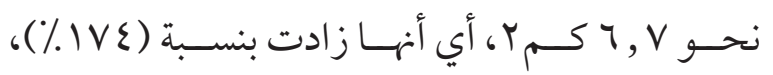

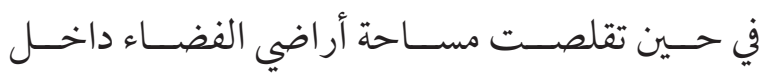

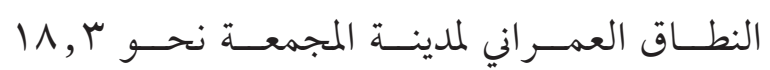

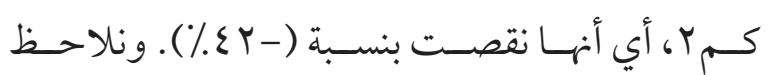

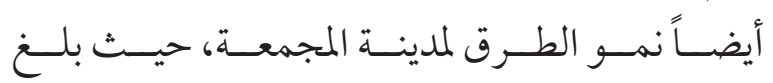

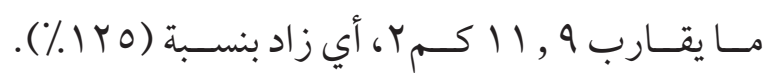

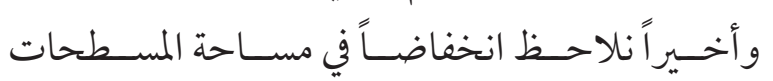

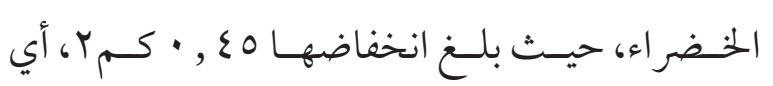

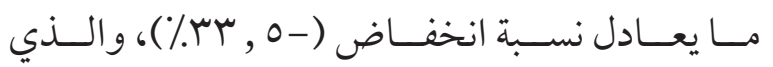
كان بسـبب تغيـير بعـض الاسـتعهالات الزراعيـة إلى نل

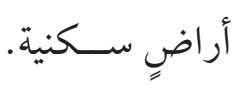

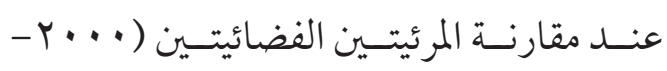

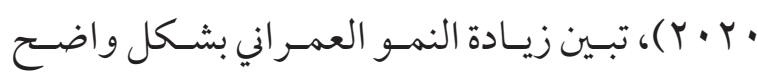

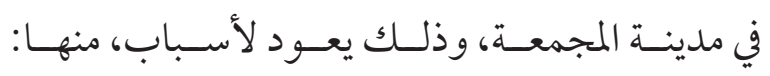

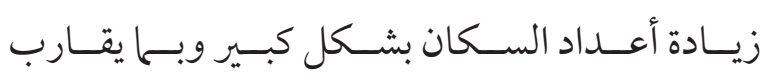

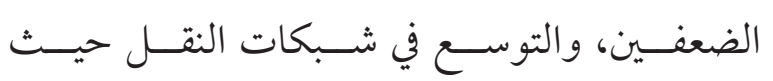

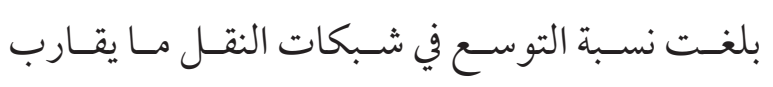

باتجاهـــا والجهــة الشــالية الشرقيسة لوجــود مشــاريع

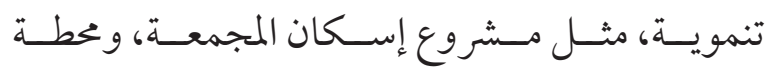

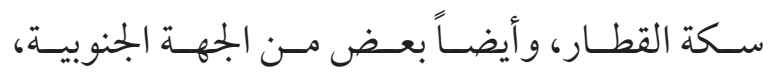
وكان ذلــك بسـبب وجــود محطــة تحليـة الميـاه ومنشـآتها.

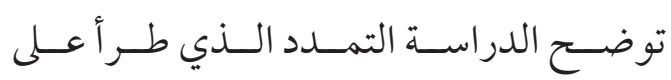

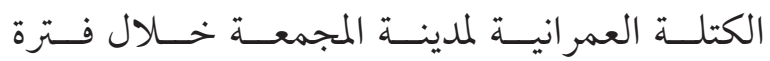

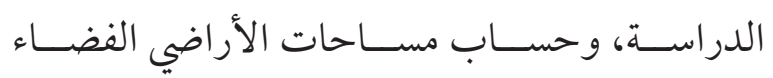

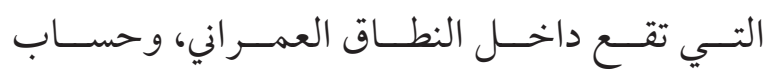

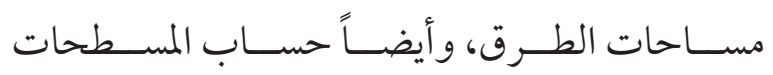

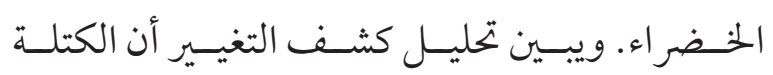

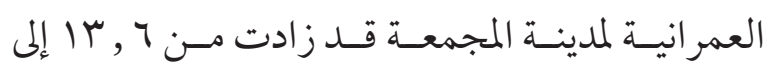

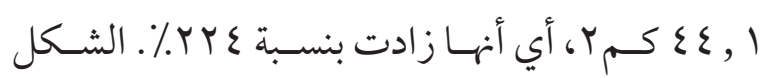
رقــم (11).

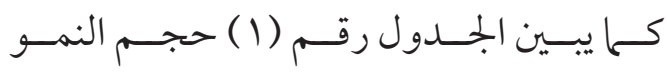

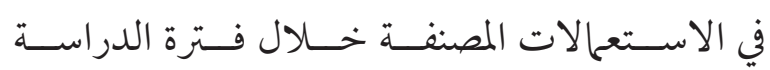

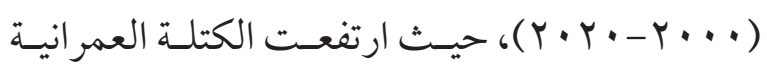

\section{المساحة بالكيلو متر المربع}
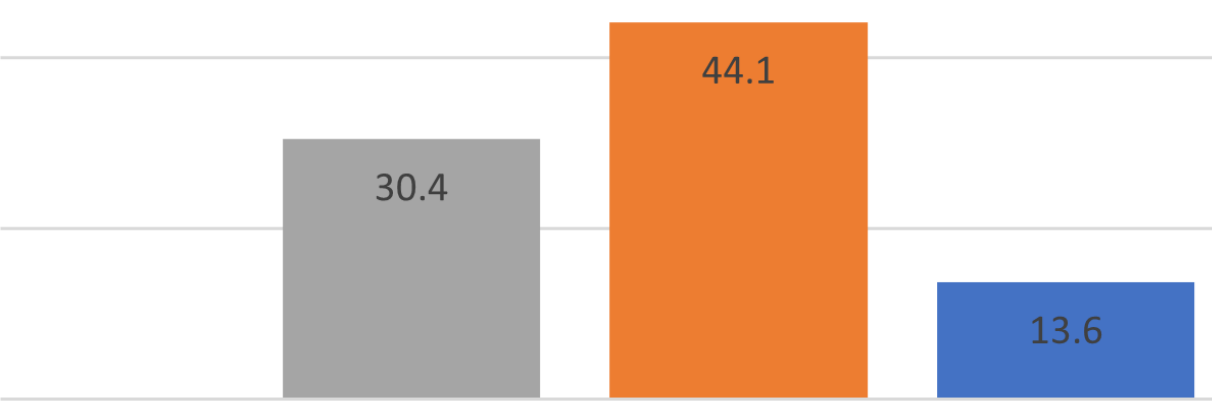

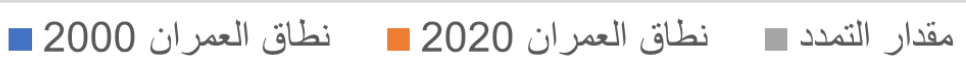

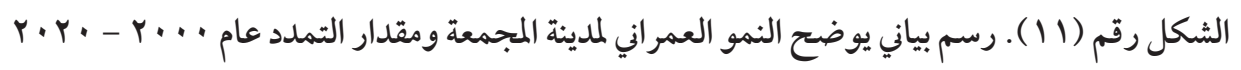




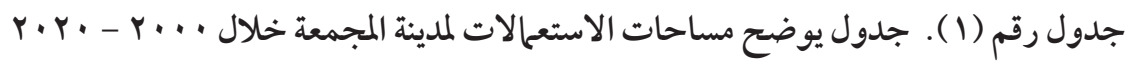

\begin{tabular}{|c|c|c|c|}
\hline الفرق & $r \cdot r \cdot$ & $r \cdots$ & الاستعمال \\
\hline$\% \operatorname{IV\varepsilon }$ & 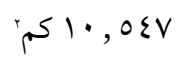 & r & المباني \\
\hline$-\% \varepsilon r, r$ & ( & 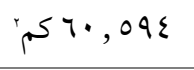 & أراضٍ فضاء مطورة وغير مطورة \\
\hline$\%$ \%ro & (1,00V & ra,ovr & طرق ط \\
\hline$-\% \mu, O$ & & ع • V ا كم & مسطحات خضراء \\
\hline
\end{tabular}

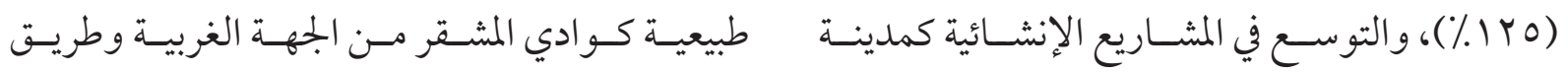

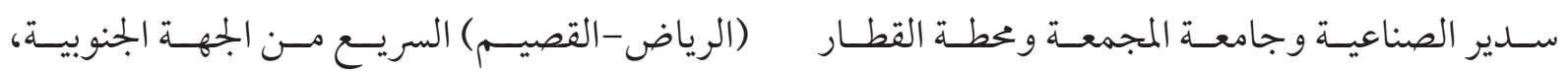

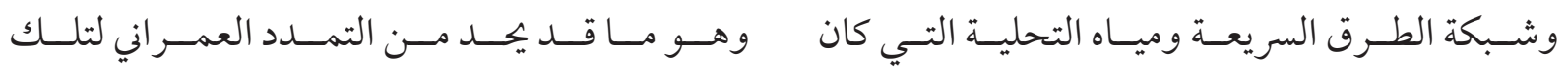

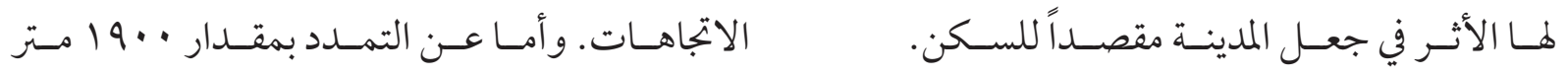

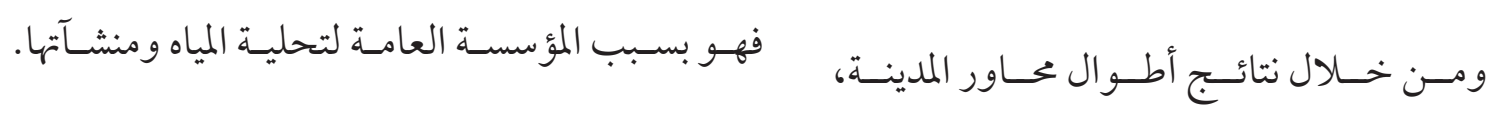

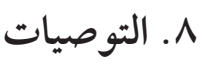

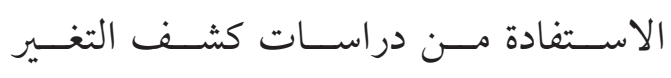

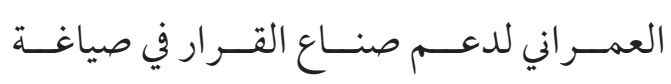

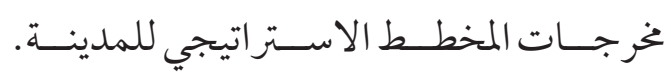

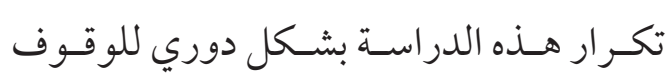

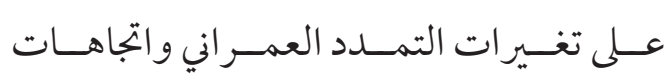

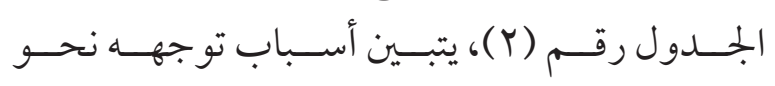

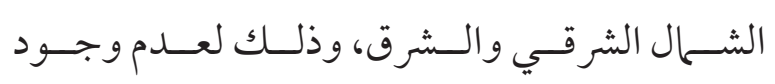

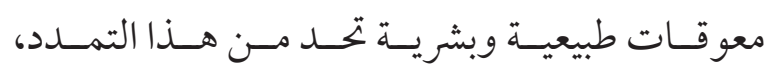

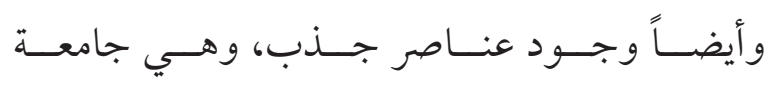

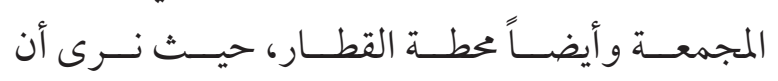

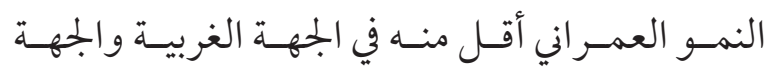

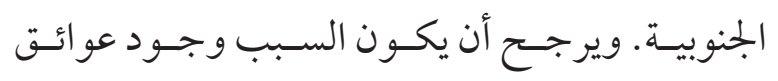

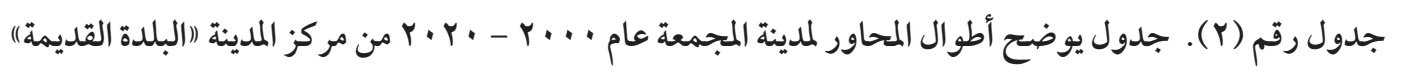

\begin{tabular}{|c|c|c|c|}
\hline الفرق & $r \cdot r$. & $r \ldots$ & الاتجاهات \\
\hline$\% \mathrm{VV}$ & م & pro.. NE & شمال شرقي \\
\hline$\% 117$ & pva.. & . . זrp & شرق \\
\hline$\% \varepsilon$ & م & prr.. SE & جنوب شرقي \\
\hline - & p $19 .$. & $-\mathrm{S}$ & جنوب \\
\hline
\end{tabular}


معيـض.،

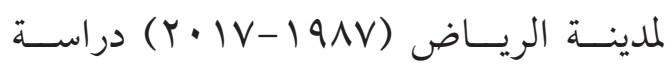

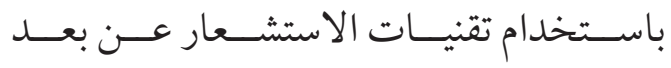

ونظـــم المعلومــات الجغر افيــة، مجلــة العـلمارة

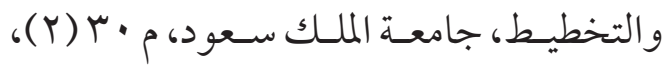

الريــاض، المملكـــة العربيــة الســعودية.

الســدحان، عبـد الله بـن نـاصر . با • ب ، مــاذا فعلـت

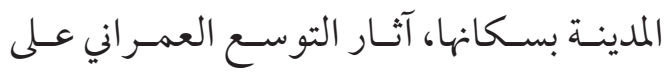

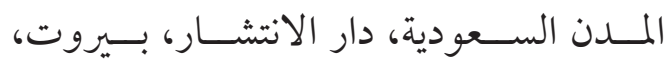

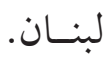

عفيفـي، احمــد كــال الديــن. 9 × · ب، التخطيــط

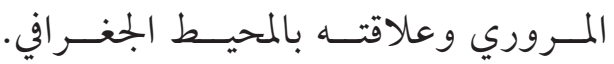

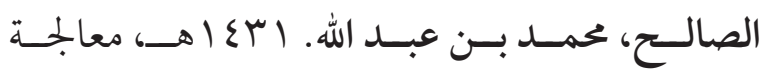

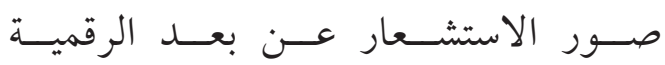

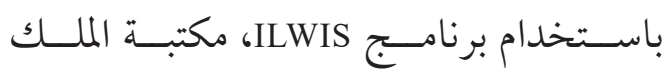

فهـــد الوطنيـة، الريــاض، المملكـــة العربيــة

الســعودية.

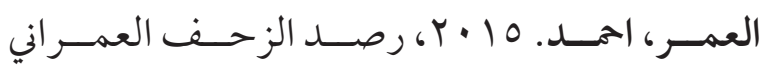

لمدينــة حـــص ومـــا حولهــا بــين عامسي

l9VY و • 1 · ب باسـتخدام تقنيات الاستشـعار

عـن بعـد ونظـم المعلو مـات الجغر افيـة، بجلـة

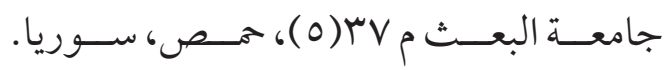

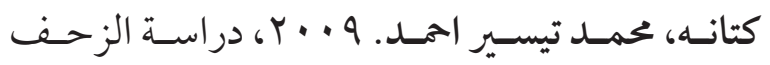

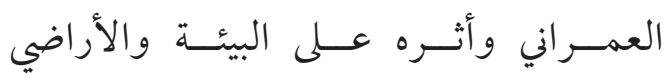

الزراعيــة في مديتــي (رام الله والبــيرة)

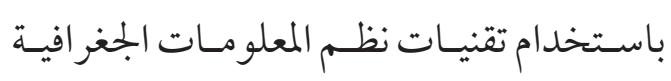

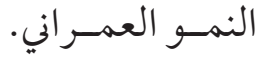

ضرورة ســنّ قوانـين وتشريعــات خاصــة

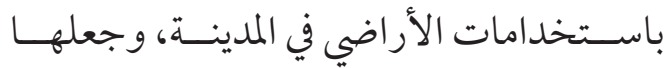

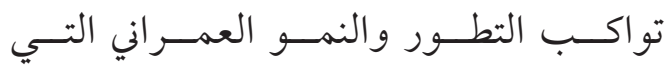

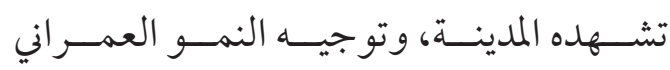

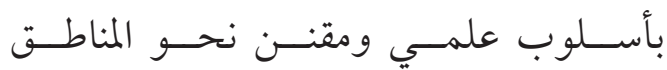

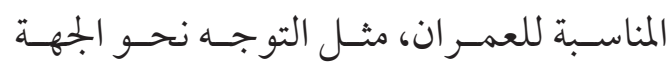
الشـــالية الشرقيــة. تحقيـق مبــدأ الاسـتدامة مسن خــلال مراقبــة

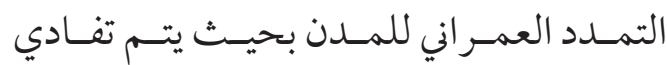

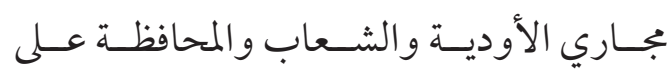
الغطــاء النبـاتي.

التوجــهـ نحـــو اســتخدام تقنيــة الاستشــار

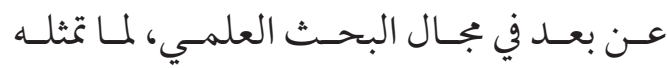

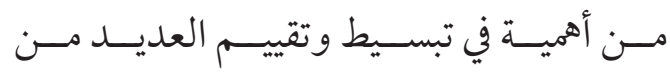

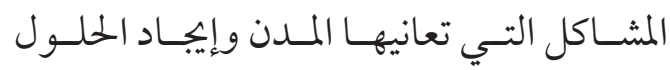
المناسـبة لهـا.

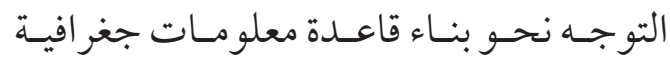
تضــم بيانـات شـاملة لمختلـف مناطـق المملكة

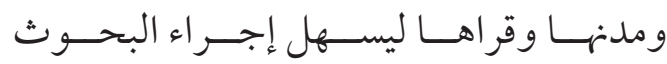
و الدر اسـات العلميـة.

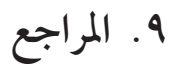

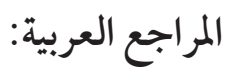

التويجــري، حمـــ أحـــد، العتيبـي، محمــد هــزاع.6

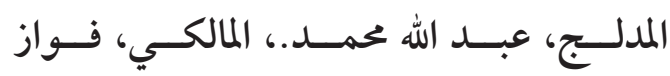


لمحافظــة المجمعــة، امانــة منطقــة الريــاض،

وزارة الشـــون البلديــة والقرويــة، المملكـــة

$$
\text { العربيـة السـعودية. }
$$

التعـــاد العـام للســكان والمســاكن، مصلحـــة

الإحصــاءات العامــة والمعلومــات، وزارة

الاقتصــاد و التخطيـط، التعــداد العام للسـكان

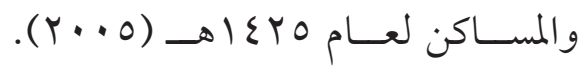

الميئـة العامـة للإحصــاء، التعــداد السـكاني للمملكـة

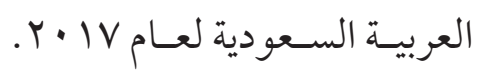

\section{Arabic References:}

Al-Tuwaijri, H. A., Al-Otaibi, M. H., Medlej, A. M., Maliki, F. M., 2018, Urban expansion of the city of Riyadh (1987-2017) a study using remote sensing techniques and geographic information systems, Journal of Architecture and Planning, King Saud University, 30 (2), Riyadh, Saudi Arabia.

Al-Sadhan, A. N., 2013, What did the city do to its residents, the urban expansion of Saudi cities, Dar Al-Diffusion, Beirut, Lebanon

Afifi, A. K., 2009, Traffic planning and its relationship to the geographical environment.

Al-Saleh, M. A., 1431AH, Digital Remote Sensing Image Processing ILWIS Program, King Fahd National Library, Riyadh, Kingdom of Saudi Arabia.

Omar, A., 2015, Monitoring the urban sprawl of Homs and its environs in 1972 and 2010

Kittana, M., 2009, Study of urban sprawl and its impact on the environment and agricultural lands in the two cities (Ramallah and Al-Bireh), using geographic information systems and remote sensing techniques, (Master $\mathrm{s}$ thesis), Birzeit University, Palestine (West

$$
\begin{aligned}
& \text { و الاستشـعار عـن بعـد، (أطروحة ماجسـير)، }
\end{aligned}
$$

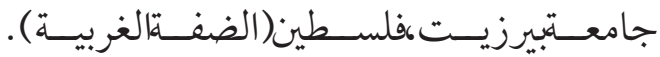

$$
\begin{aligned}
& \text { عاشـور، مصبـاح محمـد. } 0 \text { • · ץ، اسـتخدام تقنيـات } \\
& \text { نظــم المعلومــات الجغرافيــة والاستشـعار }
\end{aligned}
$$

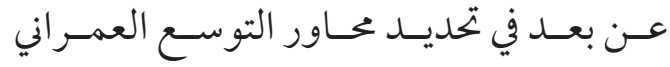

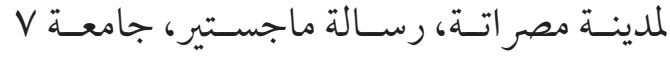

$$
\begin{aligned}
& \text { أكتوبــر، مصر اتــة، ليبيــا. }
\end{aligned}
$$

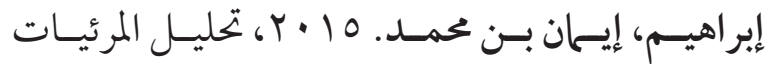

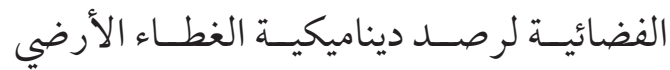

بجزيــــة تــاروت شرقــي المملكـــة العربيــة

السـعودية، المجلـة العلميـة المحكمــة لكليـة

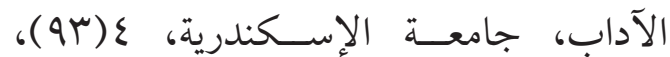

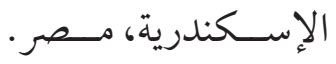

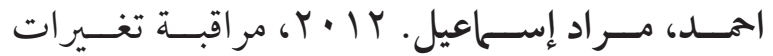

الغطـاء الارضي لنـاذج مختـارة مسن محافظـات

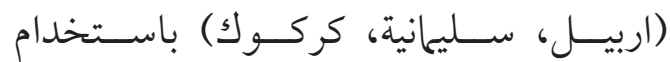

تقنيـات الاستشـعار عـن بعــــ ونظــم

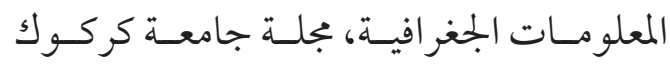

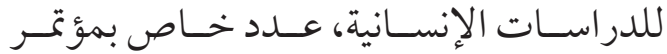

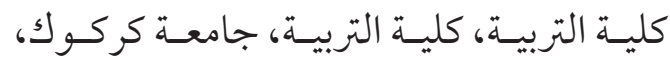

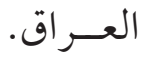

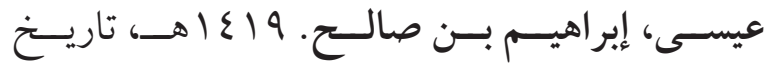

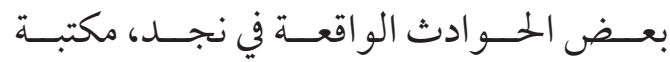

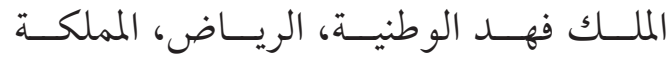

$$
\text { العربيـة الســودية. }
$$

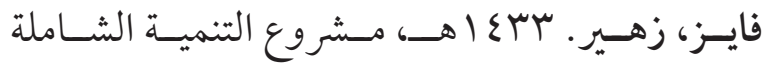




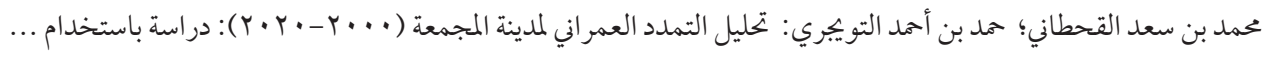

Barnes, Kent. Morgan, Jay. Roberge, Marty. Lowe, Shannon. (2001). Sprawl development: its patterns, consequences, and measurement. Towson: Towson University. Baltimore, Maryland 21252-0001

Flint, Colin. (2002). The theoretical and methodological utility of space and spatial statistics for historical studies: the Nazi party in geographic context. Historical Methods: A Journal of Quantitative and Interdisciplinary History, 35(1), 32-42.

Hegazy, I., Kaloop, M.R., 2015. Monitoring urban growth and land use change detection with GIS and remote sensing techniques in Daqahlia Governorate Egypt. International Journal of Sustainable Built Environment, http:// dx.doi.org/10.1016/j.ijsbe.2015.02.005

Ren, Pengfei. Gan, Shu. Yuan, Xiping. Zong, Huilin. Xie, Xianqi. (2013). Spatial expansion and sprawl quantitative analysis of mountain city built-up area. Geo-Informatics in Resource Management and Sustainable Ecosystem (pp. 166-176). Springer.

Xie, Chenglin. Huang, Bo. Claramunt, Christophe. Chandramouli, Magesh. (2005). Spatial logistic regression and GIS to model rural-urban land conversion. Paper presented at the proceedings of PROCESSUS second international colloquium on the behavioural foundations of inte- grated land-use and transportation models: Frameworks, models and applications.
Bank).

Ashour, M. M., 2005, The use of geographic information systems and sensing techniques for determining the axes of urban expansion in the city of Misurata, a master $>\mathrm{s}$ thesis, 7 October University, Misurata, Libya.

Ibrahim, I. M., 2015, Analysis of satellite images to monitor the dynamics of the land cover on Tarut Island, eastern Saudi Arabia, Scientific Journal of the Faculty of Arts, Alexandria University, 4 (93), Alexandria, Egypt.

Ahmed, M. I., 2012, Monitoring Land Cover Changes, Selected Review of Governorates (Erbil, Sulaymaniyah, Kirkuk) using remote sensing techniques and geographic information systems, Kirkuk University Journal of Humanitarian Studies, a special issue of education in the College of Education, College of Education, University of Kirkuk, Iraq.

Isa, I. S., $1419 \mathrm{AH}$, History of some incidents in Najd, King Fahd National Library, Riyadh, Kingdom of Saudi Arabia.

Fayez, Z., 1433 AH, Comprehensive Development Project for Majmaah Governorate, Riyadh Municipality, Ministry of Municipal and Rural Affairs, Kingdom of Saudi Arabia.

General Census, Public Housing and General Information, Ministry of Economy, General Census and Housing for the year $1425 \mathrm{AH}$ (2005).

General Authority for Statistics, Population Census of the Kingdom of Saudi Arabia for the year 2017.

\section{English References:}

Liu, Yan - Phinn, Stuart. (2003). Modelling urban development with cellular automata incorporating fuzzy-set approaches. Computers, Environment and Urban Systems, 27(6), 637-658. 


\title{
Analysis of Urban Expansion of Al-Majmaah City (2000-2020): A Study Using Geospatial Technologies and Satellite Data
}

\author{
Mohammed Saad Alqahtani \\ Riyadh Municipality, kingdom of Saudi \\ Arabia \\ haaltuwaijri@ksu.edu.sa
}

\author{
Hamad Ahmed Altuwaijri \\ Department of Geography, King Saud \\ University \\ Engm7md77@gmail.com
}

Received 17/5/2020; accepted for publication 13/9/2020

\begin{abstract}
This study analyzes urban changes in the city of Al-Majmaah during the period $2000-2020$. Al-Majmaah is considered the third-most populated city in the Riyadh region, and there is a need to know the nature of this expansion, as it is witnessing fast development as a result of many major development projects. Geographic information systems and remote sensing were used for this study. Landsat aerial imagery for the study period were uploaded through the USGS website, followed by processing and analysis operations, e.g., cropping, optimization, classification, editing, etc. Study results reveal that the rate of urban growth in Al-Majmaah City reached 224\% during the period between 2000 - 2020. The study also showed the growth trends of urban expansion for that period, as the city extended significantly towards the eastern and northeastern regions. The study recommended the use of urban change detection methodology to support decision-makers in formulating the outputs of the city's masterplan, and repeat this study periodically to determine the changes in urban sprawl and growth trends.
\end{abstract}

Key words: urban sprawl, growth trends, geographic information systems, remote sensing, satellite imagery, Al-Majmaah City. 